\title{
1 Field microenvironments regulate crop diel transcript and metabolite rhythms
}

2 Luíza Lane Barros Dantas ${ }^{1,2 *}$, Maíra Marins Dourado ${ }^{1 *}$, Natalia Oliveira de Lima ${ }^{1}$, Natale

3 Cavaçana $^{1}$, Milton Yutaka Nishiyama-Jr. ${ }^{3}$, Glaucia Mendes Souza ${ }^{1}$, Monalisa Sampaio Carneiro ${ }^{4}$,

4 Camila Caldana ${ }^{5}$, Carlos Takeshi Hotta ${ }^{1 \dagger}$

51 Departamento de Bioquímica, Instituto de Química, Universidade de São Paulo, São Paulo, SP,

$6 \quad$ 05508-000, Brazil

72 Present address: John Innes Centre, Norwich Research Park, Norwich, NR4 7UH, UK

83 Laboratório Especial de Toxicologia Aplicada, Instituto Butantan, São Paulo, SP, 05503-900,

$9 \quad$ Brazil

104 Departamento de Biotecnologia e Produção Vegetal e Animal, Centro de Ciências Agrárias,

11 Universidade Federal de São Carlos, São Carlos, SP, 13600-970, Brazil.

125 Max Planck Institute for Molecular Plant Physiology, Potsdam-Golm, Germany

$13 *$ These authors contributed equally to the work

14 Correspondence: Carlos Takeshi Hotta (hotta@iq.usp.br) - +55 (11) 3091-1224

\begin{tabular}{|l|l|}
\hline Word counts $(5,333):$ & \\
\hline Summary -194 & Discussion $-1,453$ \\
\hline Introduction -741 & Number of figures -4 \\
\hline Material and Methods $-1,294$ & Tables -0 \\
\hline Results $-1,651$ & Supporting Information -12 Figures and 2 \\
& Tables \\
\hline
\end{tabular}

15 


\section{Summary}

17 - Most research in plant chronobiology was done in laboratory conditions. However, they

18 usually fail to mimic natural conditions and their slight fluctuations, highlighting or

19 obfuscating rhythmicity. High-density crops, such as sugarcane (Saccharum hybrid), generate

20 field microenvironments with specific light and temperature due to mutual shading.

21 - We measured the metabolic and transcriptional rhythms in the leaves of 4-month-old (4 mo)

22 and 9 mo sugarcane grown in the field. Most of the assayed rhythms in 9 mo sugarcane

23 peaked $>1 \mathrm{~h}$ later than in 4 mo sugarcane, including rhythms of the circadian clock gene,

24 LATE ELONGATED HYPOCOTYL (LHY).

25 - We hypothesized that older sugarcane perceives dawn later than younger sugarcane due to

26 self-shading. As a test, we measured $L H Y$ rhythms in plants on the east and the west side of a

27 field. We also tested if a wooden wall built between lines of sugarcane changed their

28 rhythms. The $L H Y$ peak was delayed in the plants in the west of the field or beyond the wall;

29 both shaded at dawn.

30 - We conclude that plants in the same field may have different phases due to field microenvironments, impacting important agronomical traits, such as flowering time, stalk

32 weight and number.

33

34 Keywords: circadian clock, crops, field experiments, microenvironments, Saccharum hybrid,

35 shading, sugarcane 
Introduction

38 Plants are sessile organisms living in constantly changing environments. Some of those changes are rhythmic due to the movements of the tilted Earth around the sun, bringing seasons, and around itself, bringing day and night. The circadian oscillator is an adaptation for life in rhythmic environments. It is an internal regulatory network that allows plants to track the time of the day by generating responses on both metabolism and physiology levels. The ability to anticipate the rhythmic changes in the environment increases plants fitness (Green et al., 2002; Dodd et al., 2005). Plants that cannot keep their rhythms desynchronize with the environment and assimilate less carbon (C), accumulate less biomass and have lower water use efficiency (Dodd et al., 2005). pathways. The central oscillator generates rhythms independently of environmental cues (zeitgebers), such as light and temperature. Input pathways continuously feed the central oscillator with internal and external information, synchronizing it with environmental rhythms (Webb et al., 2019). Output pathways gather temporal information from the interactions between

51 the central oscillator and the input pathways and translate it into timely regulated metabolic and physiologic responses. The plant central oscillator includes several interlocked feedback loops based on the regulation of transcription and translation. For example, dawn is marked by an increase in transcripts of CIRCADIAN CLOCK ASSOCIATED 1 (CCA1, not found in monocots), LATE ELONGATED HYPOCOTYL (LHY) and REVEILLE 8 (RVE8) expression (Alabadí et al., 2001; Rawat et al., 2011; Gray et al., 2017), which in turn regulate and are regulated by the

57 expression of members of the PSEUDO RESPONSE REGULATOR (PRR) gene family during 58 the day (Nakamichi et al., 2010; Huang et al., 2012). In monocots, this includes PRR1, PRR37, PRR59, PRR73, and PRR95 (Hotta et al., 2013; Calixto et al., 2015; Dantas et al., 2020). As LHY 
61 EXPRESSION (TOC1), increases, leading to a peak near dusk (Alabadí et al., 2001). In

62 Arabidopsis thaliana (L.) Heynh., TOC1 degradation is regulated by an interplay between

63 ZEITLUPE (AtZTL) and GIGANTEA (AtGI) (Kim et al., 2007; Cha et al., 2017). In eudicots, a

64 protein complex called EVENING COMPLEX (EC) is composed of LUX ARRHTHMO (LUX),

65 EARLY FLOWERING 3 and 4 (ELF3 and ELF4) and is assembled during the night, repressing

66

67

68

69

70

71

72

73 many other central oscillator genes (Herrero et al., 2012). The EC still needs to be confirmed in monocots, even though ELF3 is present and functional (Zhao et al., 2012; Huang et al., 2017).

Experiments done in laboratory conditions frequently fail to fully mimic natural conditions, especially their rhythms (Annunziata et al., 2017; Song et al., 2018). For example, in rice (Oryza sativa L.), mutations in homolog OsGI lead to a delay in flowering in short days and long days in laboratory conditions. However, this phenotype was not observed in long days in the field (Izawa et al., 2011). In Arabidopsis, flowering under artificial conditions does not fully mimic flowering in nature due to the light quality and spectra and the temperature gradients found in natural conditions (Song et al., 2018). Arabidopsis that was grown under artificial light also had different metabolic profiles than plants grown under natural light (Annunziata et al., 2017). Rhythms in the transcription of plants grown in natural conditions or the field are regulated by the circadian oscillator and by changes in external conditions, such as temperature, light intensity, humidity, and photoperiod, or internal conditions, such as plant age and plant physiology (Nagano et al., 2012, 2019; Matsuzaki et al., 2015; Panter et al., 2019; Dantas et al., 2020). A better understanding of plant rhythms in the field is essential to translate this knowledge to agriculture (Steed et al., 2021).

Here we have measured metabolic and transcriptional rhythms in sugarcane leaves grown in the field. We show that transcript and metabolite rhythms in 4-months-old (4 mo) sugarcane have earlier peaks in the day than 9 mo sugarcane, with phase shifts ranging from $2 \mathrm{~h}$ to $12 \mathrm{~h}$. These 
85 phase shifts are correlated with changes in the peak of expression of circadian oscillator genes.

86 Such variation in the timing of the peaks was confirmed by experiments done on plants grown on

87 the east and west sides of the field or on plants that were separated by a wooden wall. We

88 conclude that external rhythms in field microenvironments regulate metabolite rhythms and

89 transcripts associated with the sugarcane circadian oscillator.

\section{$91 \quad$ Materials and Methods}

92 Field conditions, plant growth, and harvesting

93 All three assayed sugarcane fields were located in the same area, at the Federal University of São

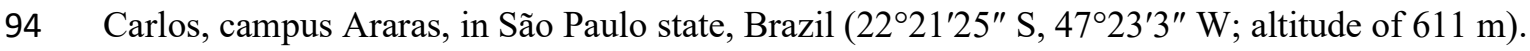

95 The soil was classified as a Typic Eutroferric Red Latosol. Sugarcane from the commercial

96 variety SP80 3280 (Saccharum hybrid) was used in all experiments. The environmental

97 conditions for the three experiments were collected from a local weather station or from within

98 the field using a handheld lux meter and a thermometer at the height of the leaves (Fig. S1). Light

99 intensity was measured with the sensor parallel to the ground. Plants were sampled every $2 \mathrm{~h}$ for

$10026 \mathrm{~h}$, starting $1.5 \mathrm{~h}$ before dawn. The leaves +1 of nine sugarcane individuals were harvested and

101 separated into three pools for all experiments, each with three individuals, and each pool was

102 considered a biological replicate. The leaves +1 are the first fully photosynthetically active leaf in

103 sugarcane. Each sampling took less than $30 \mathrm{~min}$, and the harvested tissue was immediately frozen

104 in liquid nitrogen. In the first experiment, sugarcane was planted in April/2012 and sampled in

105 August/2012 (4-months-old), during winter, and in January/2013 (9-months-old), during summer.

106 In the winter harvesting, dawn was at 6:30, and dusk was 18:00 (11.5 h day/12.5 h night). In

107 summer harvesting, dawn was at 5:45, and dusk was 19:00 (13.3 h day/10.7 $\mathrm{h}$ night). For the

108 second experiment (east and west margins), plants were planted in October/2014 and harvested in 

experiment) were also planted in October/2014 but harvested in April/2015 (6 months old) (11.3

$111 \mathrm{~h}$ day/12.7 $\mathrm{h}$ night). The orientation of the sugarcane was north to south. In the wall experiment, a

$1122 \mathrm{~m}$ high wall made of plywood sheets was built between the first and the second rows on the east

113 side of the field two days before harvest day. The time of harvesting was normalized to a

114 photoperiod of $12 \mathrm{~h}$ day/ $12 \mathrm{~h}$ night using the following equations to compare the rhythms of

115 samples harvested in different seasons: for times during the daytime, $\mathrm{ZT}=12^{*} \mathrm{~T}^{*} \mathrm{Pd}^{\wedge}(-1)$, where

$116 \mathrm{ZT}$ is the normalized time, $\mathrm{T}$ is the time from dawn (in hours), and $\mathrm{Pd}$ is the length of the day (in

117 hours); for times during the nighttime, $\mathrm{ZT}=12+12 *(\mathrm{~T}-\mathrm{Pd})^{*} \mathrm{Pn}^{\wedge}(-1)$, where $\mathrm{ZT}$ is the

118 normalized time, $\mathrm{T}$ is the time from dawn (in hours), $\mathrm{Pd}$ is the length of the day (in hours), and Pn

119 is the length of the night (in hours).

\section{Metabolome}

122 Metabolites were extracted from all 3 biological replicates. First, $50 \mathrm{mg}$ of the grounded tissue

123 was used for MTBE: methanol: water 3:1:1 (v/v/v) extraction, as described previously

124 (Giavalisco et al., 2011). Next, the $100 \mu \mathrm{l}$ of the organic phase was dried and derivatized as

125 previously described (Roessner et al., 2001). Finally, $1 \mu$ of the derivatized samples were

126 analyzed on a Combi-PAL autosampler (Agilent Technologies, St. Clara, USA) coupled to an

127 Agilent 7890 gas chromatograph coupled to a Leco Pegasus 2 time-of-flight mass spectrometer

128 (LECO, St. Joseph, MI, USA) in both split (1:40) and splitless modes (Weckwerth et al., 2004;

129 Ferreira et al., 2018). Chromatograms were exported from Leco ChromaTOF software (version

130 3.25) to R-3.1.x (R Core Team, 2021). Peak detection, retention time alignment, and library

131 matching were performed using Target Search R-package (Cuadros-Inostroza et al., 2009).

132 Metabolites were quantified by the peak intensity of a selective mass. Metabolites intensities were 
normalized by dividing the fresh-weight, followed by the sum of total ion count and global outlier

134 replacement as described previously (Giavalisco et al., 2011). Each metabolite value was further

135 normalized to Z-score. The principal component analysis was performed using pcaMethods

136 Bioconductor R package. Data ellipses were drawn for the samples harvested during the day and 137 the night ( 0.85 confidence level).

\section{Oligoarray hybridizations}

140 Oligoarrays were hybridized as described before (Hotta et al., 2013; Dantas et al., 2020). Briefly,

141 frozen samples were pulverized in dry, and $100 \mathrm{mg}$ were used for total RNA extraction using

142 Trizol (Life Technologies, Carlsbad, USA). The RNA was treated with DNase I (Life

143 Technologies, Carlsbad, USA) and cleaned using the RNeasy Plant Mini kit (Qiagen, Hilden,

144 Germany) following the supplier's recommendations. The total RNA quality was assayed using

145 an Agilent RNA 6000 Nano Kit Bioanalyzer chip (Agilent Technologies, St. Clara, USA).

146 Labelling was done following the Low Input Quick Amp Labelling protocol of the Two-Color

147 Microarray-Based Gene Expression Analysis system (Agilent Technologies, St. Clara, USA).

148 Hybridizations were done using a custom $4 \times 44 \mathrm{k}$ oligoarray (Agilent Technologies, St. Clara,

149 USA) previously described (Lembke et al., 2012; Hotta et al., 2013). Two hybridizations were

150 done for each time point against an equimolar pool of all samples of each organ. Each duplicate

151 was prepared independently using dye swaps. Data were extracted using the Feature Extraction

152 software (Agilent Technologies, St. Clara, USA). Background correction was applied to each

153 dataset. A nonlinear LOWESS normalization was also applied to the datasets to minimize

154 variations due to experimental manipulation. Signals that were distinguishable from the local

155 background signal were taken as an indication that the corresponding transcript was expressed.

156 The GenBank IDs of all sugarcane genes mentioned here can be found in the Supplemental 
157 Material (Table S1). The complete dataset can be found at the Gene Expression Omnibus public

158 database under the accession number GSE129543 and GSE171222.

161 For further analysis, only expressed transcripts in more than 6 of the 12 time points were

162 considered to be expressed. Identification of rhythmic transcripts was made using an algorithm

163 described in previous work (Dantas et al., 2020). Analyses were done in R-3.1.x (R Core Team,

164 2021). All the time series from expressed transcripts were grouped in co-expressed modules using

165 the R package weighted correlation network analysis (WGCNA) (Langfelder \& Horvath, 2008)

166 with the same parameters as before (Dantas et al., 2020). Co-expression modules were considered

167 rhythmic or non-rhythmic using JTK-CYCLE $(P$-value of $<0.75)$ (Hughes et al., 2010). LOESS

168 (locally estimated scatterplot smoothing) regression was used to establish the timing of the peak,

169 or the phase, of each rhythmic time series (Dantas et al., 2019). As controls, we also analyzed

170 rhythms using only JTK-Cycle $(P$-value of $<0.05)$ (Hughes et al., 2010) and identified only

171 transcripts with significant gene expression profile differences using the R package maSigPro

172 (Nueda et al., 2014). Euler diagrams were done using the R package eulerr. Code to fully

173 reproduce our analysis is available on GitHub (https://github.com/LabHotta/Microenvironments)

174 and archived on Zenodo (http://doi.org/10.5281/zenodo.4645464).

177 Frozen leaf samples were pulverized on dry ice using a coffee grinder (Model DCG-20, Cuisinart,

178 Stamford, USA). $100 \mathrm{mg}$ of each pulverized samples were used for total RNA extractions using 
Trizol (Life Technologies, Carlsbad, USA), according to the manufacturer's protocol. Total RNA was treated with DNase I (Life Technologies, Carlsbad, USA) and cleaned using the RNeasy Plant Mini Kit (Qiagen). Both RNA quality and concentration were checked using Agilent RNA 6000 Nano Kit Bioanalyzer chip (Agilent Technologies, St. Clara, USA). $5 \mu$ g of the purified RNA was used in the reverse transcription reactions using the SuperScript III First-Strand Synthesis System for RT-PCR (Life Technologies Cuisinart). The RT-qPCR reactions were done using Power SYBR Green PCR Master Mix (Applied Biosystems, Waltham, USA), 10× diluted cDNA, and specific primers as previously described (Hotta et al., 2013). Reactions were placed in 96-well plates and read with the Fast 7500/7500 Real-Time PCR System (Applied Biosystems, Waltham, USA). Ct determination was performed using the Fast 7500/7500 Real-Time PCR System built-in software (Applied Biosystems, Waltham, USA). The $2^{-\Delta C T}$ method was used to calculate relative expression, using GLYCERALDEHYDE-3-PHOSPHATE DEHYDROGENASE $(S c G A P D H)$ as a reference gene (Hotta et al., 2013). All primers used can be found in the Supplemental Material (Table S2).

\section{Results}

195 We have measured transcriptional rhythms of leaves, internodes $1 \& 2$ and internodes 5 of 9months-old (9 mo) commercial sugarcane (Saccharum hybrid, cultivar SP80 3280) grown in a

197 field in previous work (Dantas et al., 2020). We noticed that the circadian clock gene LATE ELONGATED HYPOCOTYL (ScLHY) peaked hours after dawn, which is unusual, as this gene is

199 light-induced in Arabidopsis (Mockler et al., 2007). To further investigate this disparity, we 200 measured ScLHY rhythms in 4 mo sugarcane leaves that had been harvested from the same field 201 (Fig. 1a). ScLHY peaked $0.2 \mathrm{~h}$ after dawn in 4 mo sugarcane leaves but peaked $2.7 \mathrm{~h}$ after dawn in 9 mo sugarcane leaves (Fig. 1b). We also observed a second $S c L H Y$ peak that starts increasing 
bioRxiv preprint doi: https://doi.org/10.1101/2021.04.08.439063: this version posted June 25,2021 . The copyright holder for this preprint (which was not certified by peer review) is the author/funder, who has granted bioRxiv a license to display the preprint in perpetuity. It is made available under aCC-BY-ND 4.0 International license. harvested from the middle of the field to avoid margin effects.

\section{a}
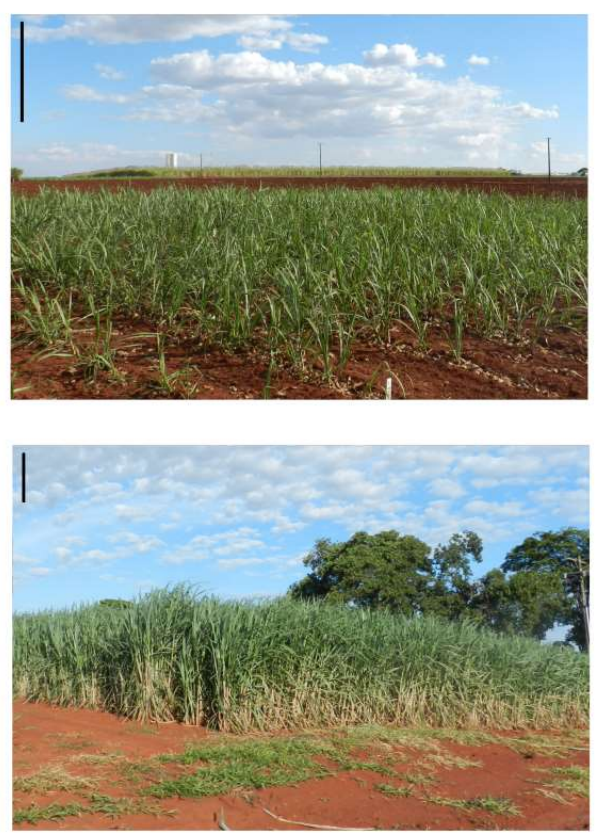

b
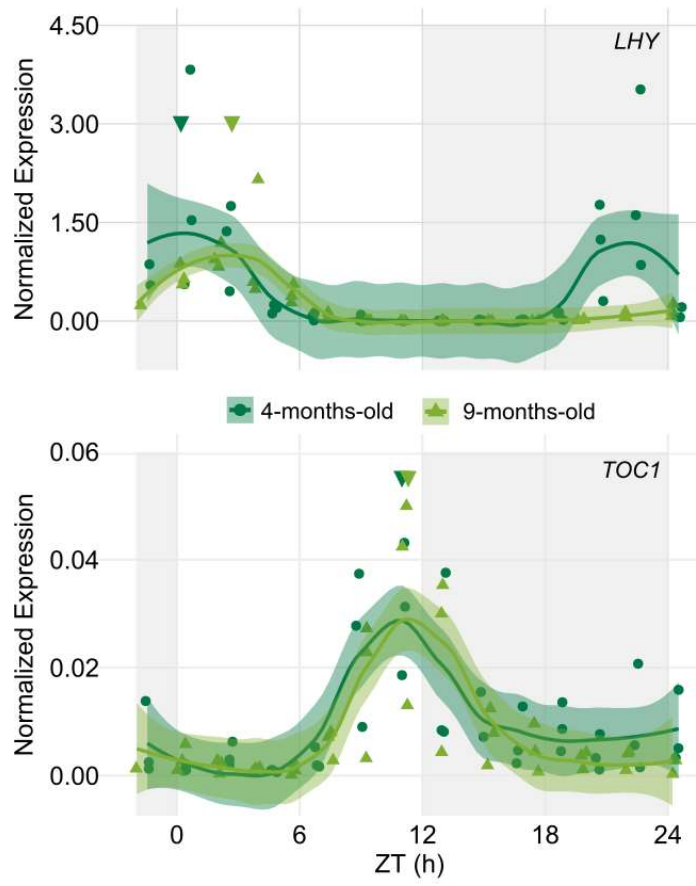

Fig. 1. Sugarcane leaves have different $S c L H Y$ phases in field-grown sugarcane. (a) Leaves from sugarcane grown for 4 months old (mo) (upper photo) and 9 mo (lower photo) in the field were harvested for $26 \mathrm{~h}$. Bar $=0.5 \mathrm{~m}$. (b) Leaves from sugarcane grown for $4 \mathrm{mo}$ and $9 \mathrm{mo}$ in the field were harvested for 26 h. (A) Diel rhythms of LATE ELONGATED HYPOCOTYL (SCLHY) and TIME OF CAB EXPRESSION $I$ (ScTOC1) in the leaves of 4 mo (dark green) and 9 mo (light green) sugarcane leaves. When sugarcane is 4 months old (left), there is little shading between plants. In comparison, 9 mo sugarcane shade each other when the sun is at a low angle (right). Bar $=0.5 \mathrm{~m}$. All biological replicates and their LOESS curve (continuous lines \pm SE) are shown. Inverted triangles show the time of the maximum value of the LOESS curve. Time series were normalized using Z-score. To compare the rhythms of samples harvested in different seasons, the time of harvesting (ZT) was normalized to a photoperiod of $12 \mathrm{~h}$ day/ $12 \mathrm{~h}$ night. The light-grey boxes represent the night periods. Transcript levels were measured using RT-qPCR. Relative expression was determined using GLYCERALDEHYDE-3-PHOSPHATE DEHYDROGENASE

$219(S c G A P D H)$.

221 To check if other transcriptional rhythms showed a peak change similar to $S c L H Y$, we used custom Agilent oligoarrays to measure transcript accumulation in 4 mo sugarcane leaves. We 
bioRxiv preprint doi: https://doi.org/10.1101/2021.04 08.439063; this version posted June 25, 2021. The copyright holder for this preprint (which was not certified by peer review) is the author/funder, who has granted bioRxiv a license to display the preprint in perpetuity. It is made available under aCC-BY-ND 4.0 International license.

223 used the transcriptomic data to detect rhythms in 4 mo sugarcane leaves using WGCNA to

224 generate co-expression modules and JTK-Cycle to identify rhythmic modules (Fig. S2). There

225 were 8,553 expressed transcripts in 4 mo sugarcane leaves, $86 \%$ of the expressed transcripts

226 found in 9 mo sugarcane leaves $(9,891)$ (Fig. 2a). We considered 4,143 of the expressed

227 transcripts were rhythmic in 4 mo sugarcane leaves (48.4\%), lower than in 9 mo sugarcane leaves

228 (68.3\%, Fig. S3a). About half of the transcripts that were rhythmic in both 4 mo and 9 mo

229 sugarcane leaves peaked earlier in the older plants (51.5\%), whilst $48.2 \%$ peaked within $1 \mathrm{~h}$ of

230 each other $(1.65 \pm 1.8 \mathrm{~h}$, median $\pm \mathrm{MA}, \mathrm{n}=4,110)$ (Fig. $2 \mathrm{~b})$. Thus, the phase changes can be seen

231 in transcripts peaking during the whole $24 \mathrm{~h}$ cycle, and not just at the same time as $S c L H Y$ peaks

232 (Fig. S3b). These phase changes were also observed using only JTK-Cycle to identify rhythmic

233 transcripts with phase estimates using JTK_Cycle $(1.56 \pm 1,9 \mathrm{~h}$, median \pm MA, $\mathrm{n}=1,014)$ or

234 using LOESS (3.62 $\pm 0.4 \mathrm{~h}$, median \pm MA, $\mathrm{n}=1014)$ (Figs S4a-d). If only transcripts with

235 significant gene expression profile differences identified with maSigPro were used, the phases

236 differences were $1.65 \pm 1.7 \mathrm{~h}$ (median \pm MA, $\mathrm{n}=1,539$ ) using LOESS, and $1.55 \pm 2.1 \mathrm{~h}$ (median

$237 \pm$ MA, $\mathrm{n}=527$ ) using JTK-Cycle (Fig. S4e). 
bioRxiv preprint doi: https://doi.org/10.1101/2021.04.08.439063; this version posted June 25, 2021. The copyright holder for this preprint (which was not certified by peer review) is the author/funder, who has granted bioRxiv a license to display the preprint in perpetuity. It is made available under aCC-BY-ND 4.0 International license.

a

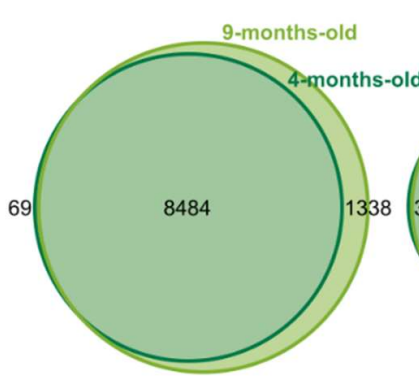

Expressed and rhythmic
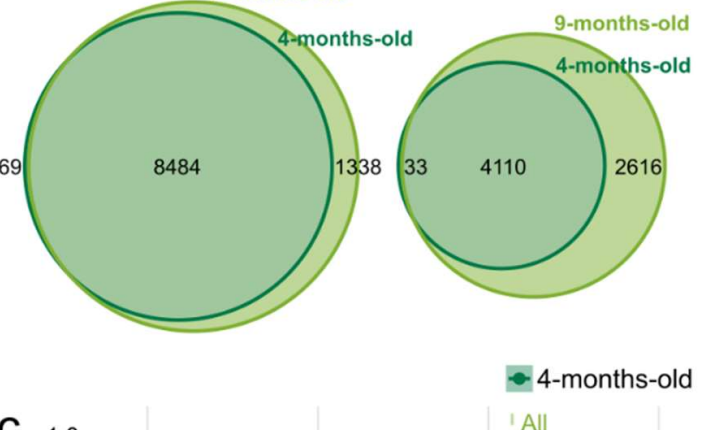

- 4-months-old $*$ 9-months-old
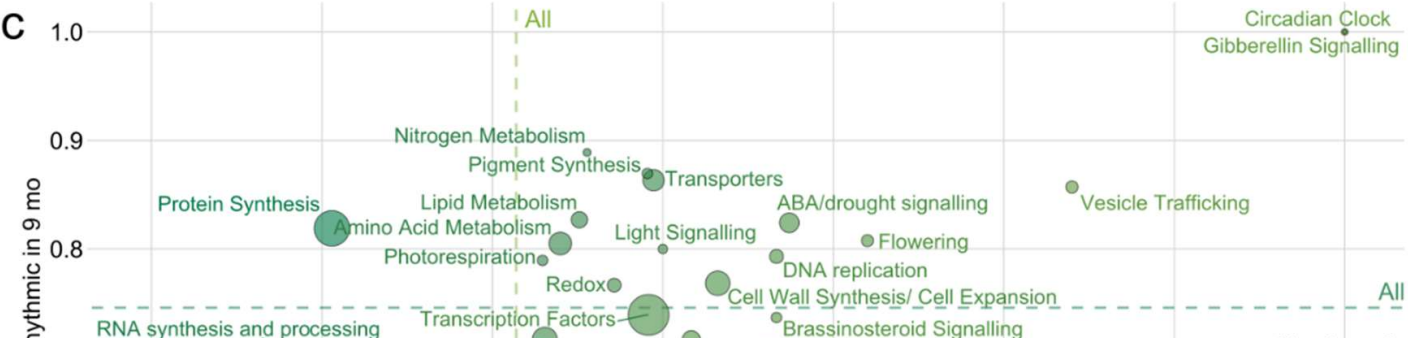

RNA synthesis and processing Transcription Factors

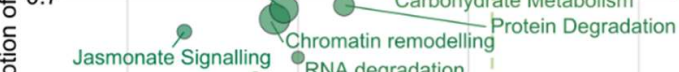

응 $\quad \begin{aligned} & \text { Jasmonate Signalling RNA degradation } \\ & \text { Cytokinin Signalling }\end{aligned}$

0.4
Cell Wall Synthesis/_Cell Expansion

Brassinosteroid Signalling Signalling

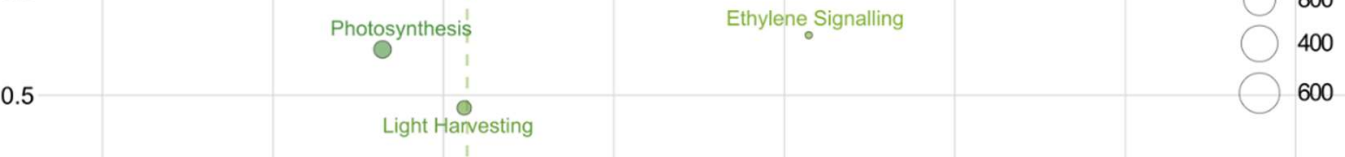

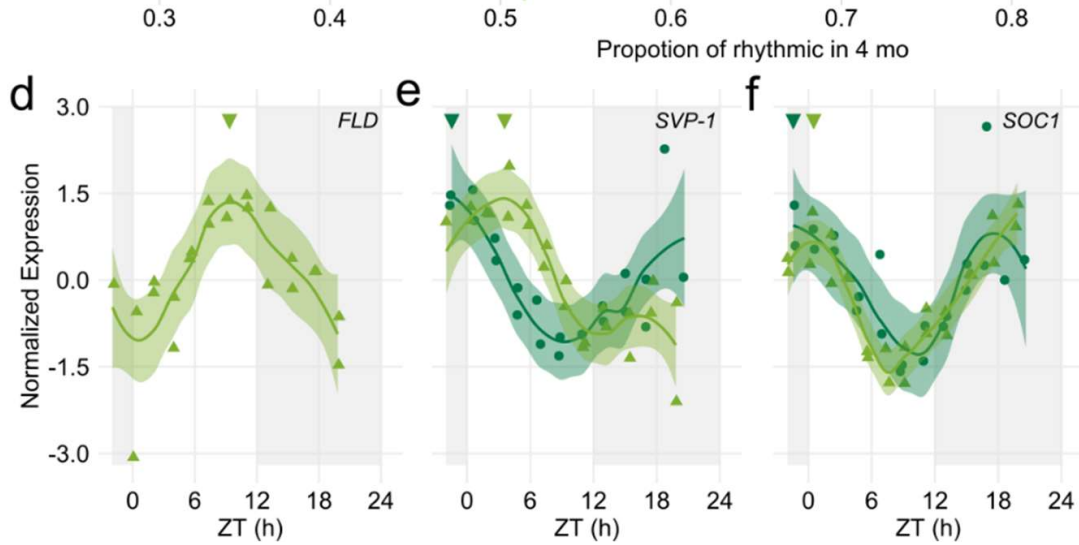

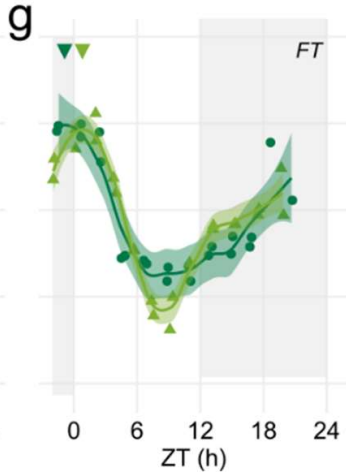

Fig. 2. Field-grown sugarcane has transcriptional rhythms with different phases. Leaves from of all expressed transcripts and expressed transcripts that are rhythmic in 4 mo (dark green) and 9 mo (light green) sugarcane leaves in diel conditions. (b) Distribution of phase differences between rhythmic transcripts from 4 mo and 9 mo sugarcane. Phase differences under $\pm 1 \mathrm{~h}$ are not considered significant (red dashed line). (c) The proportion of rhythmic transcripts in different functional categories in 4 mo and 9 mo sugarcane leaves. The size of the circles shows the total number of expressed transcripts in each category. The colour of the circles shows if there is an increase in the proportion of rhythmic transcripts in 4 mo 
bioRxiv preprint doi: https:/doi.org/10.1101/2021.04.08.439063: this version posted June 25,2021 . The copyright holder for this preprint (which was not certified by peer review) is the author/funder, who has granted bioRxiv a license to display the preprint in perpetuity. It is made available under aCC-BY-ND 4.0 International license.

(light green) or in 9 mo sugarcane leaves (dark green). The dotted lines represent the proportion of rhythmic transcripts among all annotated transcripts. (d) FLOWERING LOCUS D (ScFLD), (e) SHORT VEGETATIVE-1 (ScSVP-1), (f) SUPPRESSOR OF CONSTANS OVEREXPRESSION (ScSOC1), and (g) FLOWERING LOCUS T (ScFT) rhythms measured in 4 mo and 9 mo sugarcane. All biological replicates and their LOESS curve (continuous lines $\pm \mathrm{SE}$ ) are shown. Inverted triangles show the time of the maximum value of the LOESS curve. Time series were normalized using Z-score. To compare the rhythms of samples harvested in different seasons, the time of harvesting (ZT) was normalized to a photoperiod of $12 \mathrm{~h}$ day/ $12 \mathrm{~h}$ night. The light-grey boxes represent the night periods.

Among the other central oscillator genes investigated, PSEUDO RESPONSE REGULATOR 73 (ScPRR73), ScPRR59, ScGI, REVEILLE 8 (ScRVE8) and EARLY FLOWERING 3 (ScELF3) also peaked at similar times in 4 mo and 9 mo sugarcane leaves, while ScPRR95 had an earlier peak ($2.6 \mathrm{~h}$ ) in 9 mo sugarcane leaves (Fig. S5). We also have analyzed the proportion of rhythmic transcripts in different functional categories (Figs 2c and S3c). The Circadian Clock, ABA/drought signalling, Gibberellin Signalling, Transporters, and Flowering are examples of functional categories with a higher proportion of rhythmic transcripts than the average.

Conversely, Chromatin Remodeling and RNA Synthesis and processing are functional categories with lower rhythmic transcripts than the average. Among the disproportionately rhythmic categories in either 4 mo or 9 mo sugarcane leaves, Auxin Signalling and Ethylene Signalling have a higher proportion of rhythmic transcripts in 4 mo sugarcane leaves. In comparison, Protein Synthesis has a higher proportion of rhythmic transcripts in 9 mo sugarcane leaves (Figs 2c and $\mathrm{S} 3 \mathrm{c})$.

One important pathway that could be affected by phase changes in rhythmic genes is flowering signalling. Several sugarcane genes associated with flowering had their transcription patterns changed. For example, FLOWERING LOCUS D (ScFLD), a histone acetylase, is only expressed in 9 mo sugarcane leaves, with a peak at ZT9 (Fig. 2d). Mutation of FLD in Arabidopsis (He et al., 2003) and RNA interference of its homolog in rice(Shibaya et al., 2016) delays flowering. The flowering genes: CONSTITUTIVE PHOTOMORPHOGENIC 1 (ScCOP1) (Tanaka et al., 
277 (ScSVP-1 and -3) (Higgins et al., 2010), SUPPRESSOR OF CONSTANS OVEREXPRESSION 1

278 (ScSOC1) (Higgins et al., 2010), FLOWERING LOCUS T (ScFT) (Abdul-Awal et al., 2020), and

279 APETALA (ScAP1) (Preston \& Kellogg, 2006) peak an average $2 \mathrm{~h}$ earlier in 4 mo sugarcane

280 leaves, except for ScSVP-2 (Figs 2e-f and S6).

281 We also measured metabolite rhythms in 4 mo and 9 mo sugarcane leaves (Fig. 3). The metabolic

282 profiles of plants harvested during the day and the night cluster separately, except for the leaves

283 harvested $21 \mathrm{~h}$ after dawn (zeitgeber time 21, ZT21) in 4 mo sugarcane and leaves harvested at

284 ZT01 in 9 mo sugarcane (Fig. 3a). 31 out of 57 metabolites (54.4\%) were found rhythmic in 4 mo

285 sugarcane leaves, whereas 33 out of 51 metabolites $(64.7 \%)$ were found rhythmic in 9 mo

286 sugarcane leaves. Most of the 20 metabolites that were rhythmic in both plants (75\%) peaked

287 later in 9 mo sugarcane (Figs $3 \mathrm{~b}$ and S7). Thus, the phase changes observed in ScLHY, but not in

288 ScTOC1, are also widespread among transcriptional and metabolic rhythms. Only 2 metabolites,

289 Sucrose and myo-Inositol, peaked later in 4 mo sugarcane than in 9 mo sugarcane (Figs $3 \mathrm{~b}$ and

290 S8a). As myo-Inositol has a broader peak, possibly due to a second peak, in 4 mo sugarcane

291 compared to 9 mo sugarcane, this phase-estimate might not be accurate (Fig. S8a). Three

292 metabolites peaked within a $1 \mathrm{~h}$ difference (Figs 3d and S8b-c), 10 metabolites peaked $1.5 \mathrm{~h}$ to 6

$293 \mathrm{~h}$ later in 9 mo sugarcane (Fig. 3e and Fig. S9), and 5 metabolites peaked $8 \mathrm{~h}$ to $13 \mathrm{~h}$ later in $9 \mathrm{mo}$

294 sugarcane (Figs $3 \mathrm{f}$ and S10). The atypical night peak seen in ScLHY was also observed in

295 metabolites such as Alanine (Fig. 3e), Phenylalanine (Fig. S8b), Leucine (Fig. S9b) and Glycerate

296 (Fig. S9e). 
bioRxiv preprint doi: https://doi.org/10.1101/2021.04.08.439063; this version posted June 25, 2021. The copyright holder for this preprint (which was not certified by peer review) is the author/funder, who has granted bioRxiv a license to display the preprint in perpetuity. It is made available under aCC-BY-ND 4.0 International license.
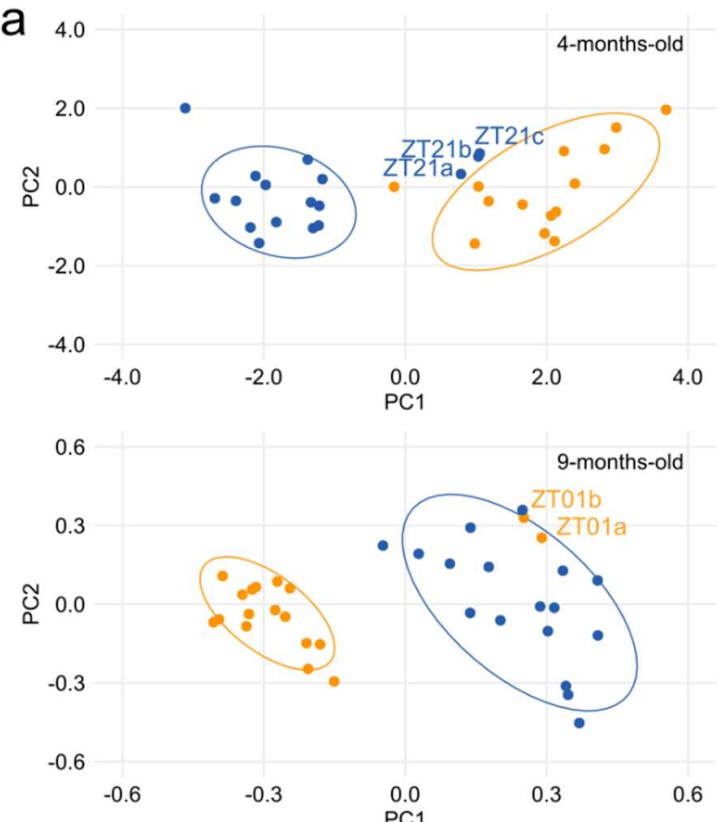

C

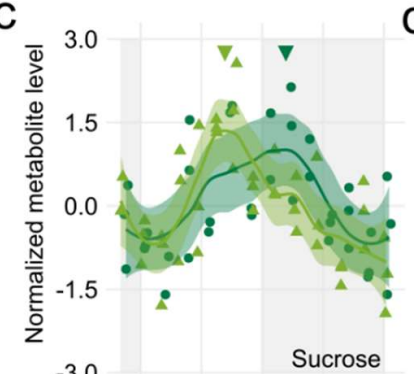

e

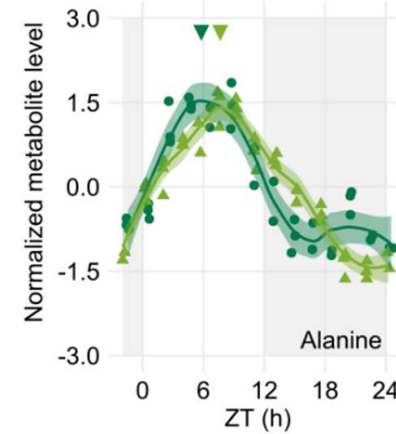

d

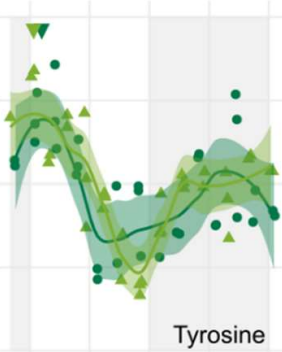

f

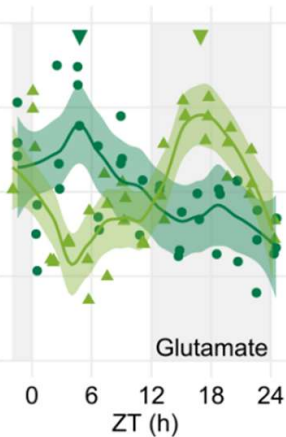

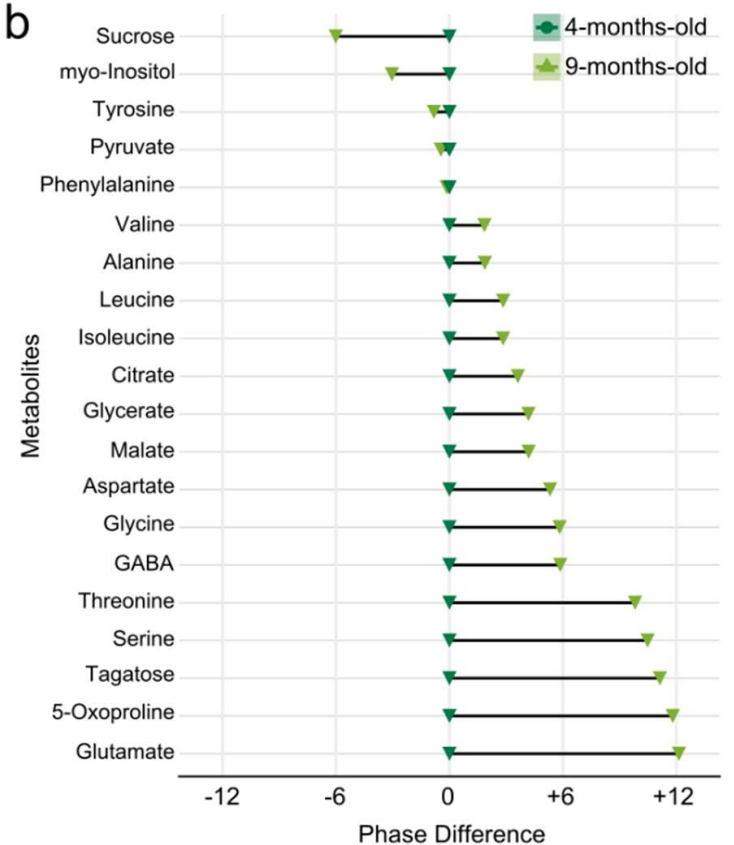

g
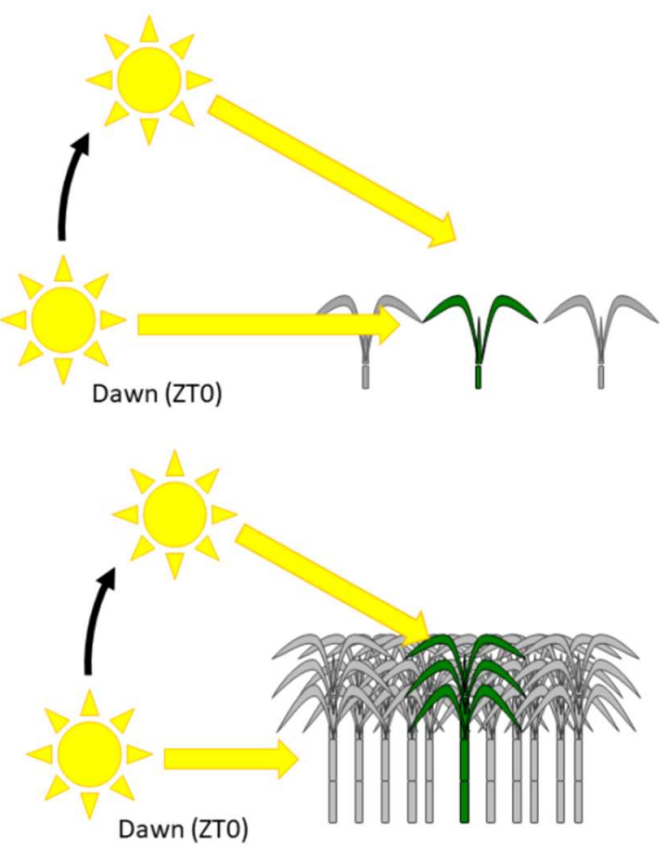

Fig. 3. Field-grown sugarcane has metabolic rhythms with different phases. (a) Principal Component Analysis (PCA) of the metabolic data from the leaves of $4 \mathrm{mo}$ and 9 mo sugarcane during the day (yellow) or during the night (blue). The percentages of total variance represented by the principal component 1 (PC1) and principal component 2 (PC2) is $63.7 \%$ and $60.3 \%$. Metabolites identified in less than $70 \%$ of the samples and samples with less than $70 \%$ of the total metabolites identified were excluded from the PCA. Data ellipses were drawn for the samples harvested during the day and the night ( 0.85 confidence level). (b) Phase difference in metabolites that were considered rhythmic in both 4 mo (dark green) and 9 mo plants (light green). (c-f) Rhythms of (c) Sucrose, (d) Tyrosine, (e) Alanine, and (f) Glutamate in 4 mo 
bioRxiv preprint doi: https:/doi.org/10.1101/2021.04.08.439063: this version posted June 25,2021 . The copyright holder for this preprint (which was not certified by peer review) is the author/funder, who has granted bioRxiv a license to display the preprint in perpetuity. It is made available under aCC-BY-ND 4.0 International license.

(dark green) and 9 mo plants (light green). (g) When sugarcane is 4 months old (left), there is little shading between plants. In comparison, 9 mo sugarcane shade each other when the sun is at a low angle (right). All biological replicates (circles in 4 mo or triangles in $9 \mathrm{mo}$ ) and their LOESS curve (continuous lines \pm SE) are shown. Inverted triangles show the time of the maximum value of the LOESS curve. Metabolite levels were normalized with Z-score. To compare the rhythms of samples harvested in different seasons, the time of harvesting (ZT) was normalized to a photoperiod of $12 \mathrm{~h}$ day/ $12 \mathrm{~h}$ night. The light-grey boxes represent the night period.

In Arabidopsis, $A t L H Y$ is responsive to light and temperature, marking the perception of dawn by the plant circadian oscillator(Martínez-García et al., 2000; Gould et al., 2006). Thus, we hypothesized that the observed phase changes result from the circadian oscillator of 9 mo sugarcane perceiving dawn later than 4 mo sugarcane due to shading effects from neighbouring plants. While young sugarcane plants interact little with their neighbours due to their short height, mature sugarcane plants usually grow densely surrounded by other plants and senescent leaves (Fig. 1a), shading each other, and making it difficult for low angle sunlight to reach leaves uniformly in the entire field (Fig. 3g). This hypothesis also explains why the metabolic profile of 9 mo sugarcane leaves harvested at ZT01, before the $S c L H Y$ peak, was closer to the leaves harvested during the night than the plants harvested during the day (Fig. 3a).

If our hypothesis were correct, plants that grow on the east side, which receives direct sunlight at dawn, and the west side of a field would have ScLHY rhythms with different phases (Fig. 4a).

Using leaves from 6 mo plants, we estimated that $S c L H Y$ from sugarcane peaked $0.6 \mathrm{~h}$ after dawn on the east side of the field and $1 \mathrm{~h}$ later on the west side (Fig. 4b). Light levels were also around $1 \mathrm{~h}$ late on the west side in the morning (Fig. S1c). Moreover, the $S c L H Y$ transcript levels changed around $800 \mathrm{x}$ during the day in sugarcane on the east side and $350 \mathrm{x}$ in sugarcane on the west side. The peak of ScLHY was $4.5 \mathrm{x}$ higher in sugarcane on the east side, affecting the phase and amplitude of downstream rhythms (Ni et al., 2009). ScPRR73 and ScPRR37 on the east side show one broad peak, while they have two smaller peaks on the west side (Figs S11a,b). In 
contrast, ScTOC1 rhythms had similar phases (Fig. 4b). We concluded that the location of a plant

334 within a field could change the perception of dawn by the circadian clock due to differences in

335 the inner field microenvironment, even if no developmental differences between plants on each

336 side of the field could be detected. In a similar experiment, grape berries (Vitis vinifera L.)

337 harvested from the east and the west side of a vine had different phases in sucrose rhythms

338 (Reshef et al., 2019).

339 To further confirm our hypothesis, we created artificial shading by building a wooden wall

340 between the first two lines of 5 mo sugarcane on the east side of the field (Fig. 4c). The wall was

341 built two days before harvesting to avoid developmental effects and any long-term shade

342 avoidance responses caused by shading. Plants ahead the wall received direct sunlight at dawn,

343 while plants beyond the wall received direct sunlight $0.7 \mathrm{~h}$ later (Fig. S1e), affecting the local

344 temperature (Fig. S1f). In sugarcane growing ahead of the wall, ScLHY expressed in leaves

345 peaked $1.1 \mathrm{~h}$ after dawn, whereas $S c L H Y$ peaked $2.4 \mathrm{~h}$ after dawn in leaves beyond the wall (Fig.

$3464 \mathrm{~d})$. The $S c L H Y$ transcript levels changed $400 \mathrm{x}$ during the day in sugarcane ahead of the wall and

$347950 \mathrm{x}$ in sugarcane beyond the wall. The peak of $S c L H Y$ was $1.7 \mathrm{x}$ higher in sugarcane ahead of

348 the wall. The ScPRR73 and ScPRR37 amplitudes are lower in sugarcane beyond the wall.

349 ScPRR37 also peaks $1.3 \mathrm{~h}$ later in sugarcane beyond the wall (Figs S11c,d). ScTOC1 peaked at

350 the same time in both conditions (Fig. 4d). These last two experiments show that the phase

351 changes seen in 4 mo and 9 mo sugarcane leaves are not a consequence of seasonal or

352 developmental differences, as plants of the same age that were harvested simultaneously were

353 used. Combining the three experiments, the peaks of ScLHY and ScTOC1 happened $10.4 \pm 0.5 \mathrm{~h}$

$354(\mathrm{n}=3)$ apart in plants not subjected to shading at dawn, and $8.7 \pm 0.5 \mathrm{~h}(\mathrm{n}=3)$ apart in plants

355 shaded at dawn, which could be enough to trigger photoperiodic responses. 
bioRxiv preprint doi: https://doi.org/10.1101/2021.04.08.439063; this version posted June 25, 2021. The copyright holder for this preprint (which was not certified by peer review) is the author/funder, who has granted bioRxiv a license to display the preprint in perpetuity. It is made available under aCC-BY-ND 4.0 International license.

a
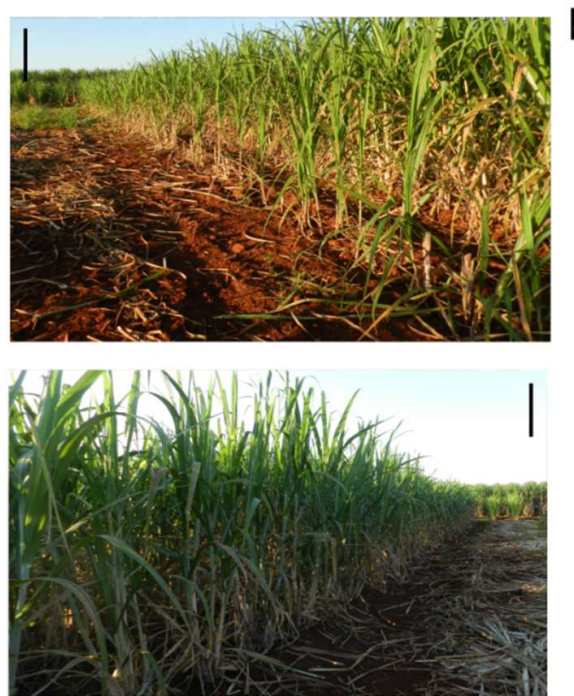

C
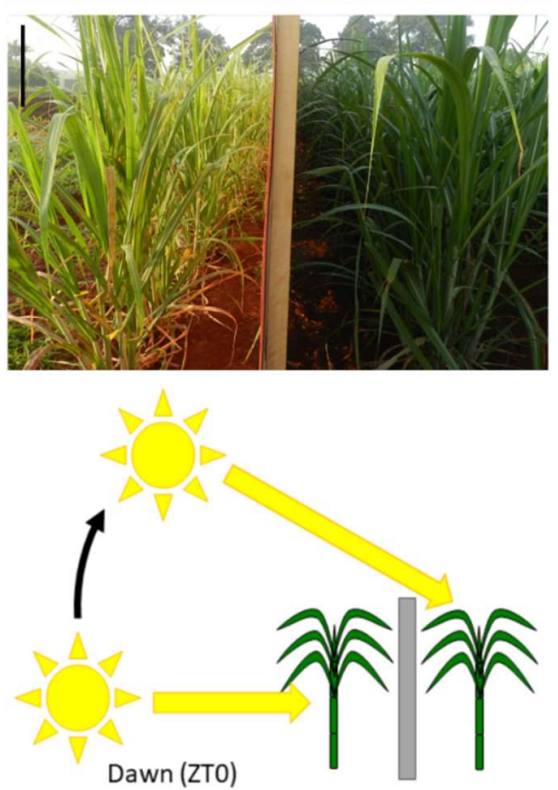

b
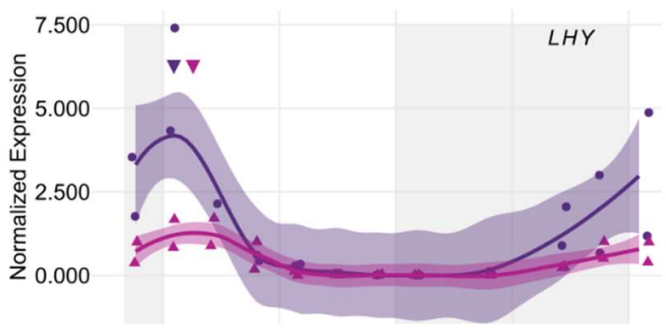

0.006

- east side west side

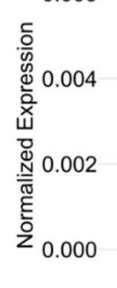

d 4.200

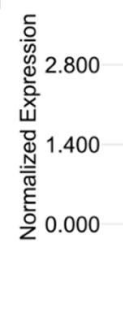

ain
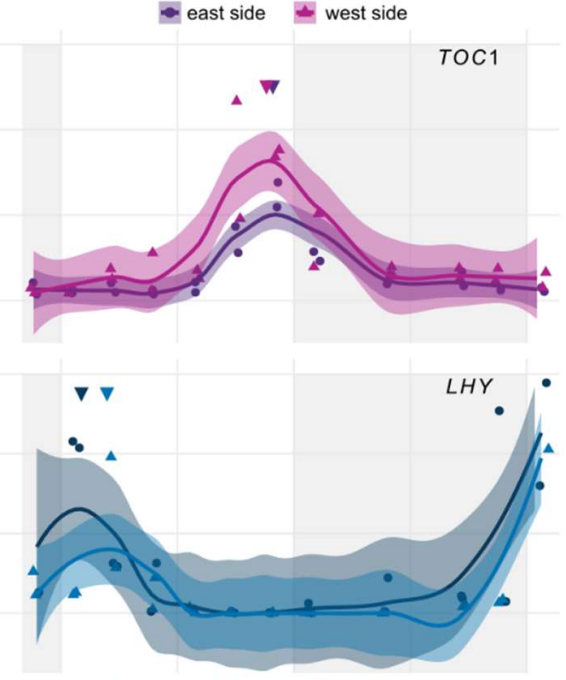

ahead of the wall beyond the wall

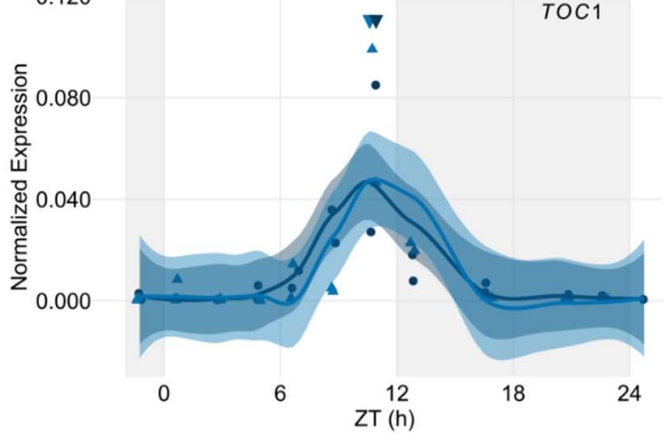

Fig. 4. Sugarcane leaves have different $S c L H Y$ phases when shaded at dawn. (a) Leaves from sugarcane grown on the east side (upper photo) and the west side (bottom photo) of the field were harvested for $26 \mathrm{~h}$. Bar $=0.5 \mathrm{~m}$. (b) Diel rhythms of LATE ELONGATED HYPOCOTYL (ScLHY) and TIME OF CAB EXPRESSION 1 (SCTOC1) in the leaves of sugarcane grown on the east side (purple) and the west side (pink) of the field. (c) Leaves from sugarcane grown before a wooden wall and after the wooden wall were harvested for $26 \mathrm{~h}$. The photo was taken $1 \mathrm{~h}$ after dawn and horizontally flipped. Bar = $0.5 \mathrm{~m}$. (d) Diel rhythms of $S c L H Y$ and $S c T O C 1$ in sugarcane leaves grown ahead of the wall (dark blue) and beyond the wall (light blue). All biological replicates and their LOESS curve (continuous lines $\pm \mathrm{SE}$ ) are shown. Inverted triangles show the time of the maximum value of the LOESS curve. Time series were normalized using Z-score. To compare the rhythms of samples harvested in different seasons, the time of harvesting (ZT) was normalized to a photoperiod of $12 \mathrm{~h}$ day/ $12 \mathrm{~h}$ night. The light-grey boxes represent the night periods. Transcript levels were measured using RT-qPCR. Relative expression was determined using GLYCERALDEHYDE-3-PHOSPHATE DEHYDROGENASE (SCGAPDH). 


\section{Discussion}

371 We found that the location of a plant within a field can change the perception of dawn by the 372 circadian clock due to differences in field microenvironments. The circadian clock regulates

373 carbon allocation, which may impact agronomic traits (Yazdanbakhsh et al., 2011; Kölling et al.,

374 2015). Among the circadian clock genes, only ScLHY and ScPRR95 had their phase changed

375 when comparing 4 mo and 9 mo sugarcane leaves, explaining why only half of the rhythmic

376 genes had phase changes. However, change in the expression of these two genes can trigger

377 changes that affect the timing of a vast number of output rhythms, as hundreds of genes are

378 regulated directly by AtLHY and AtPRR95 in Arabidopsis (Harmer et al., 2000; Liu et al., 2016;

379 Adams et al., 2018).

Diel rhythms could be driven by environmental rhythms, the circadian oscillator, or their synergic combination. Among the external factors, temperature, light quality and quantity, photoperiod and photosynthesis are known to be essential regulators of plant rhythms (Martínez-García et al., 2000; Gould et al., 2006; Frank et al., 2018; Dantas et al., 2019). While it is tempting to attribute the phase differences to light, temperature may be an important factor driving sugarcane rhythms. In Brachypodium dystachion (L.) P. Beauv., another grass species, changes in temperatures were

386 found to be the main environmental cue driving rhythmic behaviour (Matos et al., 2014;

387 MacKinnon et al., 2020). In sugarcane, temperature also regulates the rate of $S c L H Y$ isoform

388 formation by alternative splicing (Dantas et al., 2019). Temperature rhythms were very different

389 when 4 mo sugarcane was harvested (temperature between $10^{\circ} \mathrm{C}$ and $27^{\circ} \mathrm{C}$ ) from when 9 mo

390 sugarcane was harvested (temperature range between $16^{\circ} \mathrm{C}$ and $30^{\circ} \mathrm{C}$ ) (Fig. S1b). This

391 temperature difference may also explain the differences in the number of rhythmic transcripts and

392 metabolites (Pyl et al., 2012; Annunziata et al., 2018). In Arabidopsis, differences in temperatures affected the levels of $A t L H Y, A t C C A 1$ and AtPRR9 (a probable ortholog of 
394 ScPRR95), which included a delay in peak time (Bieniawska et al., 2008; Gould et al., 2013;

395 Annunziata et al., 2018). We should also stress that the 4 mo and 9 mo sugarcane leaves were

396 under different photoperiods $(11.5 \mathrm{~h}$ day/12.5 $\mathrm{h}$ and $13.3 \mathrm{~h}$ day $/ 10.7 \mathrm{~h}$ night, respectively), which

397 could be another factor explaining some differences among rhythms, as seen in Arabidopsis

398 halleri subsp. gemmifera (Matsum.) O'Kane \& Al-Shehbaz in natural conditions (Nagano et al.,

399 2019). However, plants in the other experiments were harvested at the same time.

400 Sugarcane rhythms may also be regulated by shade avoidance responses, as the R: FR ratio could

401 be altered due to shading from other plants. Even though little is known about the regulation of

402 the circadian clock by shade-avoidance responses, changes in plant density have been correlated

403 to changes in the circadian clock genes. In Sorghum bicolor (L.) Moench. at high and low

404 densities, changes in transcription levels of $S b L H Y$ and $S b T O C 1$ were correlated with differences

405 in internode length (Kebrom et al., 2020). As only one time point was sampled in that study, if

406 sorghum had similar phase differences as the ones we detected, they would be seen as differences

407 in expression levels, as seen when only one timepoint is considered in our experiments (Fig. S12).

408 When row spacings in sugarcane fields were changed between $1.5 \mathrm{~m}$ and $2.3 \mathrm{~m}$, cane yields ( $\mathrm{t} / \mathrm{ha})$

409 were maintained, as the stalk numbers and weight would change in response to different plant

410 densities (Garside et al., 2009; Chiluwal et al., 2018).

411 Microenvironment changes due to shading also affect photosynthesis. In Arabidopsis,

412 photosynthetic soluble sugars have been shown to regulate the circadian oscillator (Haydon et al.,

413 2013; Frank et al., 2018). Hence, the phase changes seen in ScLHY could be driven by changes in

414 photosynthesis or, specifically, by carbon assimilation into sucrose. Moreover, photosynthesis is

415 one of the factors that impact rhythms in gene expression in A. halleri subsp. gemmifera in

416 natural conditions (Nagano et al., 2019). It is unclear how the circadian oscillator and metabolites

417 rhythms are interconnected in sugarcane. However, Sucrose was one of the only metabolites with 
418 an earlier phase in the leaves of 9 mo sugarcane (Figs 3b,c). Indeed, Sucrose levels in the first $4 \mathrm{~h}$

419 of the day were similar in 4 mo and 9 mo plants. Thus, Sucrose from photosynthesis might not be

420 the factor explaining the observed phase changes, but our analysis only covered a few

421 photosynthetic metabolites. As rhythmic differences in Sucrose were distinct from the changes

422 observed in other metabolites, it is possible that it is dependent on a different internal or external

423 factor. One possible explanation is a reduction of the photosynthesis in the afternoon due to

424 shading of sugarcane in the middle of the field, or the inhibition of photosynthesis due to Sucrose

425 accumulation in the leaves and internodes (McCormick et al., 2008).

426 In 4 mo sugarcane leaves, $S c L H Y$ and other transcripts showed an unexpected transcriptional peak

427 in the middle of the night in 4 mo sugarcane (Figs $1 \mathrm{~b}$ and S3a). We do not know what could have

428 triggered this peak in transcript expression, but metabolites, such as Alanine, Glycerate and

429 Phenylalanine, showed the same peak. A similar peak in the middle of the night was found in

430 Coffea arabica L. and attributed to moonlight effects (Breitler et al., 2020). In our experiment,

431 the increase in transcriptional and metabolic levels during the night started minutes after the

432 crescent moon was set (ZT17-18). Thus, we do not think moonlight or other artificial lights with

433 similar intensity or spectrum were the factors driving these increases. However, this night peak of

434 unknown origin shows that metabolites and transcripts are interconnected and that the metabolic

435 changes brought by photosynthesis and light signalling are not the only force driving rhythms

436 during the day. For example, we have seen significant phase shifts in metabolites $(>8 \mathrm{~h})$ between

4374 mo and 9 mo sugarcane. The differences, seen in Glutamate, GABA, Serine, 5-Oxoproline,

438 Tagatose and GABA (Figs 3f, S9i and S10), may be due to differences in plant age. In Nicotiana

439 tabacum (L.), a similar phase change was observed in the rhythms of Glutamate and GABA in the

440 sink and the source leaves (Masclaux-Daubresse et al., 2002). This change was associated with

441 the rhythmic expression of GLUTAMATE DEHYDROGENASE 1 (NtGDH1) in the source leaves 
442 but no expression in sink leaves. In 4 mo sugarcane, an $S c G D H 1$ was arrhythmic, with expression

443 below the detection levels in many time points (Fig. S5i). In 9 mo sugarcane, ScGDH1 was

444 rhythmic, and expression was above detection levels in all time points.

445 Flowering is a necessary process that could be affected by phase changes in rhythmic genes. As

446 the vegetative stage is harvested, flowering is usually undesired in sugarcane, as it reduces

447 sucrose yield due to decreased growth, increased side-shoot production, and pithiness (Rao,

448 1977). Sugarcane enters the reproductive phase in response to the shortening of the photoperiod

449 over 15 days, and just a $0.5 \mathrm{~h}$ difference in photoperiod can trigger flowering in most genotypes

450 (Midmore, 1980; Moore \& Berding, 2013; Glassop et al., 2014). Thus, the correct measurement

451 of dawn and dusk is essential for flowering in sugarcane. Among those genes, $S c S V P-1, S c S V P-3$,

$452 S c S O C 1, S c F T$, and ScCDF1 peak before dawn in 4 mo sugarcane leaves and after dawn in 9 mo

453 sugarcane leaves (Figs 2e-g and S6). In Arabidopsis, AtLHY and AtCCA1 reduce AtSVP protein

454 levels, a repressor of flowering (Fujiwara et al., 2008). A change in the relative phase between

455 ScLHY and ScSVP may change the ScSVP protein levels, impacting flowering. We also found

456 that $S c P R R 37$ and $S c P R R 73$ show different expression patterns in plants shaded in the morning

457 that could be explained by the changes in the phase of two peaks during the day. In sorghum, the

458 second peak in SbPRR37, during the evening, regulates flowering (Murphy et al., 2011). Thus,

459 neighbour shading could trigger flowering earlier than the actual critical photoperiod. In

460 sugarcane, the spindle, a whorl of immature leaves on the top of the plant, perceives photoperiod,

461 which could be a strategy to reduce the effects of shading from neighbour plants (Moore \&

462 Berding, 2013; Glassop et al., 2014; Glassop \& Rae, 2019).

463 The circadian clock increases the productivity of plants when its phase matches the phase of

464 environmental rhythms (Dodd et al., 2005). It is usually accepted that the rhythms of plants under

465 the same photoperiod have matching phases. However, we have evidence that field 
466 microenvironmental rhythms and not astronomical rhythms regulate the plant circadian oscillator

467 of plants in natural, fluctuating conditions and transcriptional and metabolic rhythms. This

468 phenomenon can probably be observed in plants grown in natural or artificial environments, such

469 as crops, forests, and gardens, with microenvironments. Thus, rhythms in field

470 microenvironments are another factor to consider when translating knowledge from the lab to the

471 field, especially agriculture.

\section{Acknowledgements}

474 This work was supported by the São Paulo Research Foundation (FAPESP) (grant nos. 11/00818-

475 8, 15/06260-0 and 19/08534-0; BIOEN Program) and by the Serrapilheira Institute (grant no.

476 Serra-1708-16001). LLBD and NOL were supported by FAPESP scholarships (grants 11/08897-4

477 and 16/06740-4, respectively). We thank the support of Carolina G. Lembke for the oligoarrays

478 hybridization. We thank the support of the LabMET at the Brazilian Bioethanol Science and

479 Technology Laboratory (CTBE/CNPEM) for the metabolite profiling analysis (MET-19154 and 480 MET-20673).

\section{Author Contributions}

483 Conceptualization, LLBD, MSC, CTH; Methodology, LLBD, CTH; Software, CTH, MYN;

484 Validation, LLBD, NOL; Investigation, LLBD, NOL, CTH, CC; Resources, MSC, C. C.; Data

485 Curation, CTH, MYN; Writing - Original Draft, LLBD, CTH; Writing - Review \& Editing,

486 LLBD, MSC, CC, CTH; Visualization; C. T. H.; Project Administration, CTH; Funding

487 Acquisition, CTH. 
490 The complete dataset can be found at the Gene Expression Omnibus public database under the 491 accession number GSE129543 and GSE171222. Code to fully reproduce our analysis is available

492 on GitHub (https://github.com/LabHotta/Microenvironments) and archived on Zenodo

493 (http://doi.org/10.5281/zenodo.4645464).

500 Abdul-Awal SM, Chen J, Xin Z, Harmon FG. 2020. A sorghum gigantea mutant attenuates

501 florigen gene expression and delays flowering time. Plant Direct 4: e00281.

Adams S, Grundy J, Veflingstad SR, Dyer NP, Hannah MA, Ott S, Carré IA. 2018.

503 Circadian control of abscisic acid biosynthesis and signalling pathways revealed by genome-wide 504 analysis of LHY binding targets. New Phytologist 220: 893-907.

505 Alabadí D, Oyama T, Yanovsky MJ, Harmon FG, Más P, Kay SA. 2001. Reciprocal

506 regulation between TOC1 and LHY/CCA1 within the Arabidopsis circadian clock. Science (New

507 York, N.Y.) 293: 880-883. 

natural light environment. Journal of Experimental Botany 69: 4881-4895. controlled environments. Journal of Experimental Botany 68: 4463-4477.

516 Cold-Responsive Transcriptome. Plant Physiology 147: 263-279. arabica. BMC Plant Biology 20: 24. $108-119$. circadian clock. Nature Communications 8: 3 . 


\section{Cuadros-Inostroza A, Caldana C, Redestig H, Kusano M, Lisec J, Peña-Cortés H,} Willmitzer L, Hannah MA. 2009. TargetSearch--a Bioconductor package for the efficient preprocessing of GC-MS metabolite profiling data. BMC bioinformatics 10: 428.

Dantas LL de B, Almeida-Jesus FM, de Lima NO, Alves-Lima C, Nishiyama-Jr MY, Carneiro MS, Souza GM, Hotta CT. 2020. Rhythms of Transcription in Field-Grown Sugarcane Are Highly Organ Specific. Scientific Reports 10: 6565.

Dantas LLB, Calixto CPG, Dourado MM, Carneiro MS, Brown JWS, Hotta CT. 2019. Alternative Splicing of Circadian Clock Genes Correlates With Temperature in Field-Grown Sugarcane. Frontiers in Plant Science $\mathbf{1 0 .}$

Dodd AN, Salathia N, Hall A, Kevei E, Toth R, Nagy F, Hibberd JM, Millar AJ, Webb AA. 2005. Plant circadian clocks increase photosynthesis, growth, survival, and competitive advantage. Science 309: 630-3.

Ferreira DA, Martins MCM, Cheavegatti-Gianotto A, Carneiro MS, Amadeu RR, Aricetti JA, Wolf LD, Hoffmann HP, de Abreu LGF, Caldana C. 2018. Metabolite Profiles of Sugarcane Culm Reveal the Relationship Among Metabolism and Axillary Bud Outgrowth in Genetically Related Sugarcane Commercial Cultivars. Frontiers in Plant Science 9.

Frank A, Matiolli CC, Viana AJC, Hearn TJ, Kusakina J, Belbin FE, Wells Newman D, Yochikawa A, Cano-Ramirez DL, Chembath A, et al. 2018. Circadian entrainment in Arabidopsis by the sugar-responsive transcription factor bZIP63. Current Biology 28: 25972606.e6. 

adoption of controlled traffic. Crop and Pasture Science 60: 544-554.

Köhl K, Willmitzer L. 2011. Elemental formula annotation of polar and lipophilic metabolites spectrometry. The Plant Journal: For Cell and Molecular Biology 68: 364-376.

Glassop D, Rae AL. 2019. Expression of sugarcane genes associated with perception of photoperiod and floral induction reveals cycling over a 24-hour period. Functional Plant Biology 46: $314-327$.

Glassop D, Rae AL, Bonnett GD. 2014. Sugarcane Flowering Genes and Pathways in Relation to Vegetative Regression. Sugar Tech 16: 235-240. Arabidopsis Circadian Clock. The Plant Cell 18: 1177-1187.

567 Millar AJ, Finkenstädt B, et al. 2013. Network balance via CRY signalling controls the 
bioRxiv preprint doi: https://doi org/10.1101/2021.04.08 439063; this version posted June 25, 2021. The copyright holder for this preprint (which was not certified by peer review) is the author/funder, who has granted bioRxiv a license to display the preprint in perpetuity. It is made available under aCC-BY-ND 4.0 International license.

Gray JA, Shalit-Kaneh A, Chu DN, Hsu PY, Harmer SL. 2017. The REVEILLE Clock Genes Inhibit Growth of Juvenile and Adult Plants by Control of Cell Size. Plant Physiology 173: 23082322.

Green RM, Tingay S, Wang Z-Y, Tobin EM. 2002. Circadian rhythms confer a higher level of fitness to Arabidopsis plants. Plant Physiology 129: 576-584.

Harmer SL, Hogenesch JB, Straume M, Chang HS, Han B, Zhu T, Wang X, Kreps JA, Kay SA. 2000. Orchestrated transcription of key pathways in Arabidopsis by the circadian clock. Science (New York, N.Y.) 290: 2110-2113.

Haydon MJ, Mielczarek O, Robertson FC, Hubbard KE, Webb AA. 2013. Photosynthetic entrainment of the Arabidopsis thaliana circadian clock. Nature 502: 689-92.

He Y, Michaels SD, Amasino RM. 2003. Regulation of flowering time by histone acetylation in Arabidopsis. Science (New York, N.Y.) 302: 1751-1754.

Herrero E, Kolmos E, Bujdoso N, Yuan Y, Wang M, Berns MC, Uhlworm H, Coupland G, Saini R, Jaskolski M, et al. 2012. EARLY FLOWERING4 recruitment of EARLY FLOWERING3 in the nucleus sustains the Arabidopsis circadian clock. The Plant Cell 24: 428443.

Higgins JA, Bailey PC, Laurie DA. 2010. Comparative Genomics of Flowering Time Pathways Using Brachypodium distachyon as a Model for the Temperate Grasses. PLOS ONE 5: e10065.

Hotta CT, Nishiyama MY, Souza GM. 2013. Circadian rhythms of sense and antisense transcription in sugarcane, a highly polyploid crop. PLoS One 8: e71847. 

functions for EARLY FLOWERING 3 between monocots and dicots. Plant Direct 1: e00018. Oscillator. Science 336: 75-79.

Hughes ME, Hogenesch JB, Kornacker K. 2010. JTK_CYCLE: an efficient nonparametric Rhythms 25: 372-380. Yano M, Hirai MY, et al. 2011. Os-GIGANTEA confers robust diurnal rhythms on the global transcriptome of rice in the field. The Plant Cell 23: 1741-1755.

Kebrom TH, McKinley BA, Mullet JE. 2020. Shade signals alter the expression of circadian clock genes in newly-formed bioenergy sorghum internodes. Plant Direct 4: e00235. Somers DE. 2007. ZEITLUPE is a circadian photoreceptor stabilized by GIGANTEA in blue light. Nature 449: 356-360. 
609 Langfelder P, Horvath S. 2008. WGCNA: an R package for weighted correlation network

610 analysis. BMC bioinformatics 9: 559.

611 Lembke CG, Nishiyama MY, Sato PM, de Andrade RF, Souza GM. 2012. Identification of

612 sense and antisense transcripts regulated by drought in sugarcane. Plant Molecular Biology 79:

$613 \quad 461-477$.

614 Liu TL, Newton L, Liu M-J, Shiu S-H, Farré EM. 2016. A G-Box-Like Motif Is Necessary for

615 Transcriptional Regulation by Circadian Pseudo-Response Regulators in Arabidopsis. Plant

616 Physiology 170: 528-539.

617 MacKinnon KJ-M, Cole BJ, Yu C, Coomey JH, Hartwick NT, Remigereau M-S, Duffy T,

618 Michael TP, Kay SA, Hazen SP. 2020. Changes in ambient temperature are the prevailing cue

619 in determining Brachypodium distachyon diurnal gene regulation. New Phytologist 227: 1709_

6201724

621 Martínez-García JF, Huq E, Quail PH. 2000. Direct Targeting of Light Signals to a Promoter

622 Element-Bound Transcription Factor. Science 288: 859-863.

623 Masclaux-Daubresse C, Valadier M-H, Carrayol E, Reisdorf-Cren M, Hirel B. 2002. Diurnal

624 changes in the expression of glutamate dehydrogenase and nitrate reductase are involved in the

$625 \mathrm{C} / \mathrm{N}$ balance of tobacco source leaves. Plant, Cell \& Environment 25: 1451-1462.

626 Matos DA, Cole BJ, Whitney IP, MacKinnon KJ-M, Kay SA, Hazen SP. 2014. Daily changes

627 in temperature, not the circadian clock, regulate growth rate in Brachypodium distachyon. PloS

628 One 9: e100072. 
629 Matsuzaki J, Kawahara Y, Izawa T. 2015. Punctual transcriptional regulation by the rice

630 circadian clock under fluctuating field conditions. The Plant Cell 27: 633-648.

631 McCormick AJ, Cramer MD, Watt DA. 2008. Regulation of photosynthesis by sugars in

632 sugarcane leaves. Journal of Plant Physiology 165: 1817-1829.

633 Midmore DJ. 1980. Effects of photoperiod on flowering and fertility of sugarcane (Saccharum 634 spp.). Field Crops Research 3: 65-81.

635 Mockler TC, Michael TP, Priest HD, Shen R, Sullivan CM, Givan SA, McEntee C, Kay SA,

636 Chory J. 2007. The DIURNAL project: DIURNAL and circadian expression profiling, model-

637 based pattern matching, and promoter analysis. Cold Spring Harbor Symposia on Quantitative

638 Biology 72: 353-363.

639 Moore PH, Berding N. 2013. Flowering. In: Sugarcane: Physiology, Biochemistry, and

640 Functional Biology. John Wiley \& Sons, Ltd, 379-410.

641 Murphy RL, Klein RR, Morishige DT, Brady JA, Rooney WL, Miller FR, Dugas DV, Klein

642 PE, Mullet JE. 2011. Coincident light and clock regulation of pseudoresponse regulator protein 64337 (PRR37) controls photoperiodic flowering in sorghum. Proceedings of the National Academy

644 of Sciences of the United States of America 108: 16469-16474.

645 Nagano AJ, Kawagoe T, Sugisaka J, Honjo MN, Iwayama K, Kudoh H. 2019. Annual

646 transcriptome dynamics in natural environments reveals plant seasonal adaptation. Nature Plants

647 5: 74. 

Cell 151: 1358-1369. RESPONSE REGULATORS 9, 7, and 5 are transcriptional repressors in the Arabidopsis circadian clock. The Plant Cell 22: 594-605. rhythms regulate growth vigour in hybrids and allopolyploids. Nature 457: 327-331.

656 Nueda MJ, Tarazona S, Conesa A. 2014. Next maSigPro: updating maSigPro bioconductor

657 package for RNA-seq time series. Bioinformatics 30: 2598-2602. AN. 2019. Circadian Regulation of the Plant Transcriptome Under Natural Conditions. Frontiers in Genetics 10. APETALA1/FRUITFULL-Like Genes in Grasses (Poaceae). Genetics 174: 421-437. and Growth in Arabidopsis Depend on the Daytime Temperature but Are Temperature-

665 Compensated against Cool Nights. The Plant Cell 24: 2443-2469.

667 Rao PS. 1977. Effects of Flowering on Yield and Quality of Sugarcane. Experimental

668 Agriculture 13: 381-387. 

loop within the Arabidopsis circadian clock. PLoS genetics 7: e1001350. metabolic profile. Plant, Cell \& Environment 42: 1897-1912. Metabolic profiling allows comprehensive phenotyping of genetically or environmentally modified plant systems. The Plant Cell 13: 11-29.

677 Shibaya T, Hori K, Ogiso-Tanaka E, Yamanouchi U, Shu K, Kitazawa N, Shomura A, Ando

678 T, Ebana K, Wu J, et al. 2016. Hd18, Encoding Histone Acetylase Related to Arabidopsis

679 FLOWERING LOCUS D, is Involved in the Control of Flowering Time in Rice. Plant \& Cell Physiology 57: 1828-1838. long-day conditions in Arabidopsis. Nature Plants 4: 824-835. circadian clock to improve crop yield and sustainability. Science $\mathbf{3 7 2}$. 
bioRxiv preprint doi: https://doi org/10.1101/2021.04 08 439063; this version posted June 25,2021 . The copyright holder for this preprint (which was not certified by peer review) is the author/funder, who has granted bioRxiv a license to display the preprint in perpetuity. It is made available under aCC-BY-ND 4.0 International license.

689 Webb AAR, Seki M, Satake A, Caldana C. 2019. Continuous dynamic adjustment of the plant

690 circadian oscillator. Nature Communications 10: 550.

691 Weckwerth W, Wenzel K, Fiehn O. 2004. Process for the integrated extraction, identification

692 and quantification of metabolites, proteins and RNA to reveal their co-regulation in biochemical

693 networks. Proteomics 4: 78-83.

694 Yazdanbakhsh N, Sulpice R, Graf A, Stitt M, Fisahn J. 2011. Circadian control of root

695 elongation and C partitioning in Arabidopsis thaliana. Plant, Cell \& Environment 34: 877-894.

696 Zhao J, Huang X, Ouyang X, Chen W, Du A, Zhu L, Wang S, Deng XW, Li S. 2012.

697 OsELF3-1, an Ortholog of Arabidopsis EARLY FLOWERING 3, Regulates Rice Circadian

698 Rhythm and Photoperiodic Flowering. PLOS ONE 7: e43705.

699

700 
bioRxiv preprint doi: https://doi.org/10.1101/2021.04.08.439063; this version posted June 25, 2021. The copyright holder for this preprint (which was not certified by peer review) is the author/funder, who has granted bioRxiv a license to display the preprint in perpetuity. It is made available under aCC-BY-ND 4.0 International license.

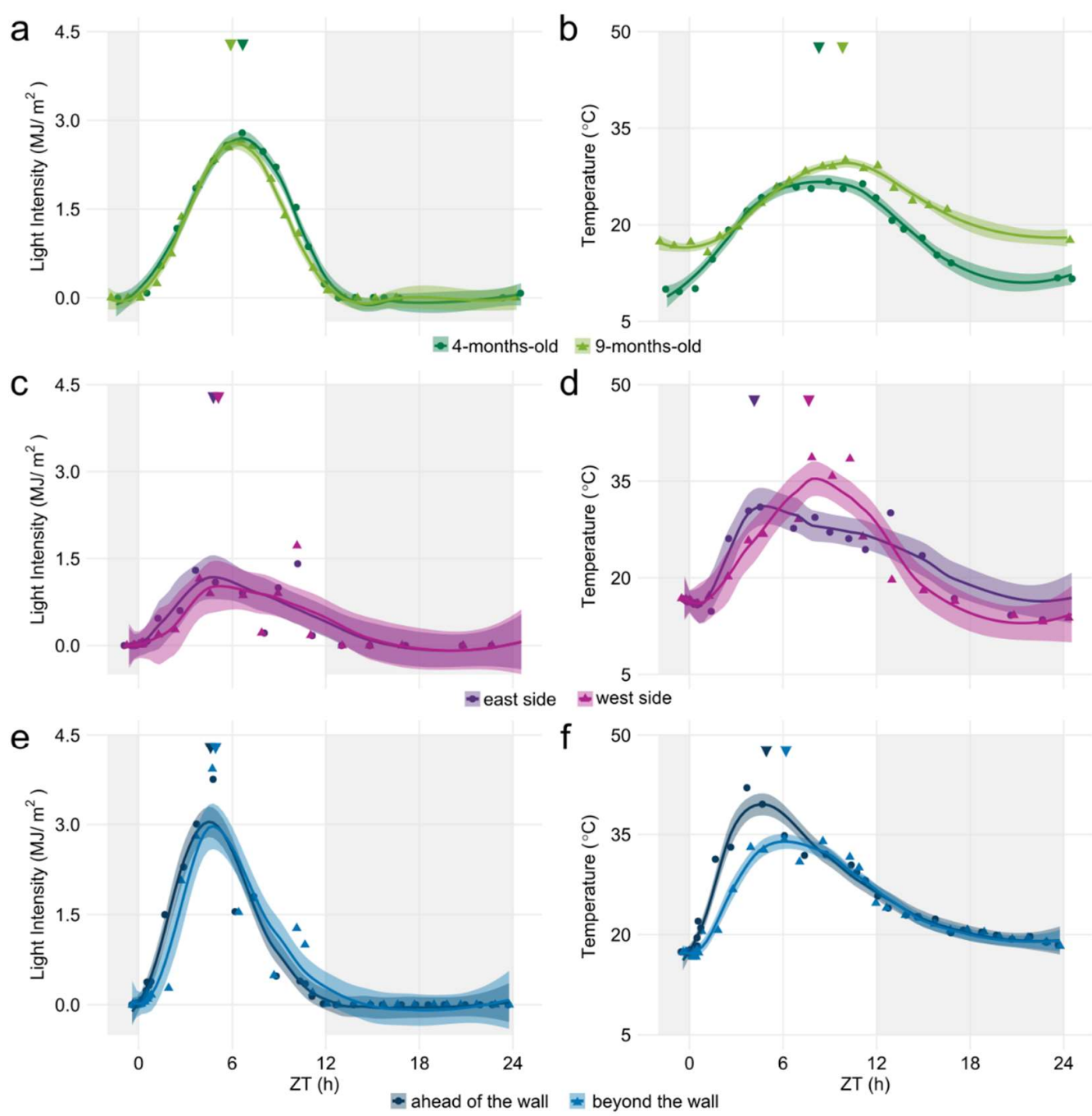

Fig. S1 - Environmental conditions in Araras (SP, Brazil). (a) Light intensity and (b) temperature on the day of harvesting 4 months old (4 mo) (green) and 9 mo (light green) sugarcane. Data was taken from a meteorological station nearby the sugarcane field, which underestimates microenvironmental changes. (c) Light intensity and (d) temperature on the day of harvesting 6 mo sugarcane in the east (purple) or the west side (pink) of the field. Data was taken from a handheld light meter and thermometer next to the plants inside the field. (e) Light intensity and (f) temperature on the day of harvesting 5 mo sugarcane in the east side of the field (dark blue) and sugarcane shaded by an artificial wall (light blue). Data was taken from a handheld light meter and thermometer next to the plants inside the field. All data and their LOESS curve (continuous lines $\pm \mathrm{SE}$ ) are shown. Inverted triangles show the time of the maximum value of the LOESS curve. To compare the rhythms of samples harvested in different seasons, the time of 714 harvesting (ZT) was normalized to a photoperiod of $12 \mathrm{~h}$ day/ $12 \mathrm{~h}$ night. The light-grey boxes 715 represent the night period. 
bioRxiv preprint doi: https://doi.org/10.1101/2021.04.08.439063; this version posted June 25, 2021. The copyright holder for this preprint (which was not certified by peer review) is the author/funder, who has granted bioRxiv a license to display the preprint in perpetuity. It is made available under aCC-BY-ND 4.0 International license.
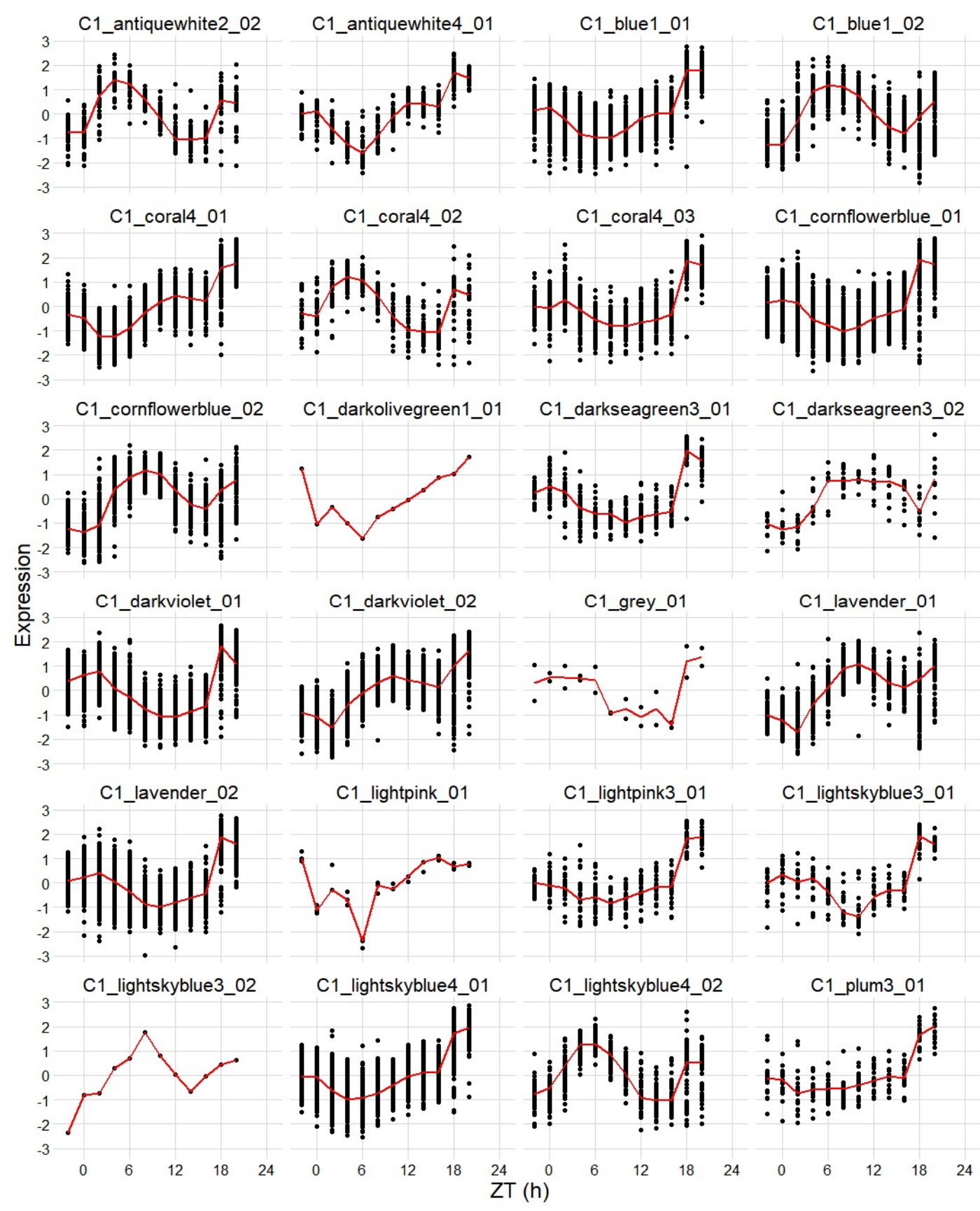

Fig. S2 - Rhythmic co-expression modules that were identified in 4-months-old sugarcane leaves. Weighted correlation network analysis was used to group co-expressed transcripts in modules. Rhythmic modules were identified using JTK-cycle. The time course generated from the median of all time points is in red. 
bioRxiv preprint doi: https://doi.org/10.1101/2021.04 08.439063; this version posted June 25, 2021. The copyright holder for this preprint (which was not certified by peer review) is the author/funder, who has granted bioRxiv a license to display the preprint in perpetuity. It is made available under aCC-BY-ND 4.0 International license.

\section{Supplemental Figure 3}
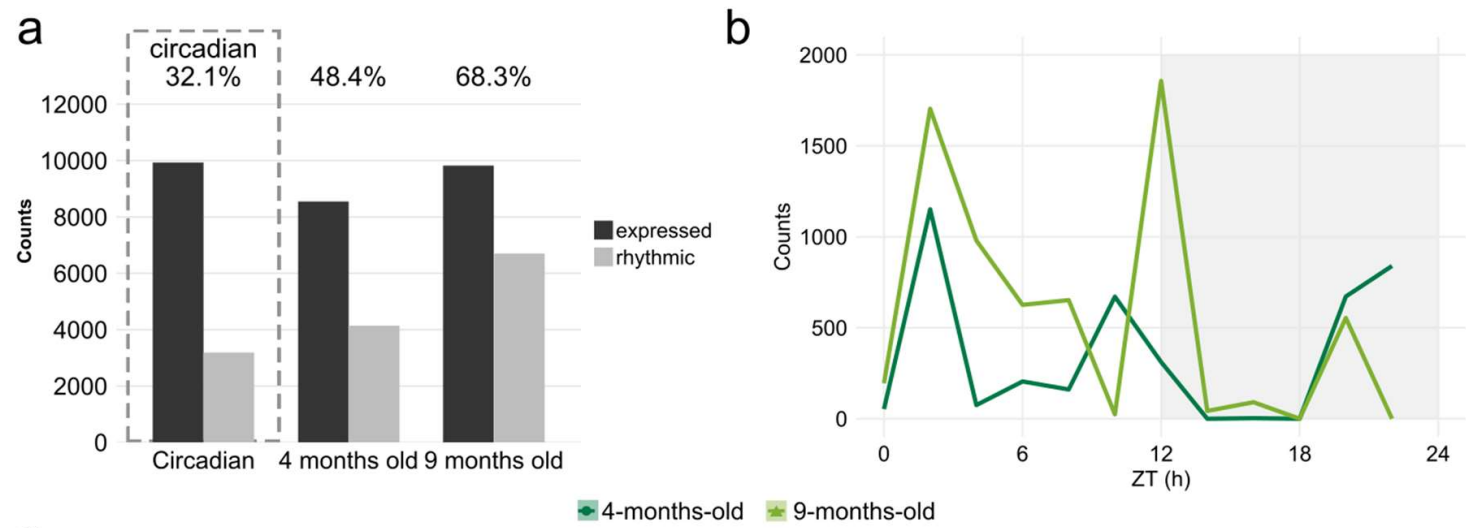

C

- 4-months-old $\equiv$-months-old

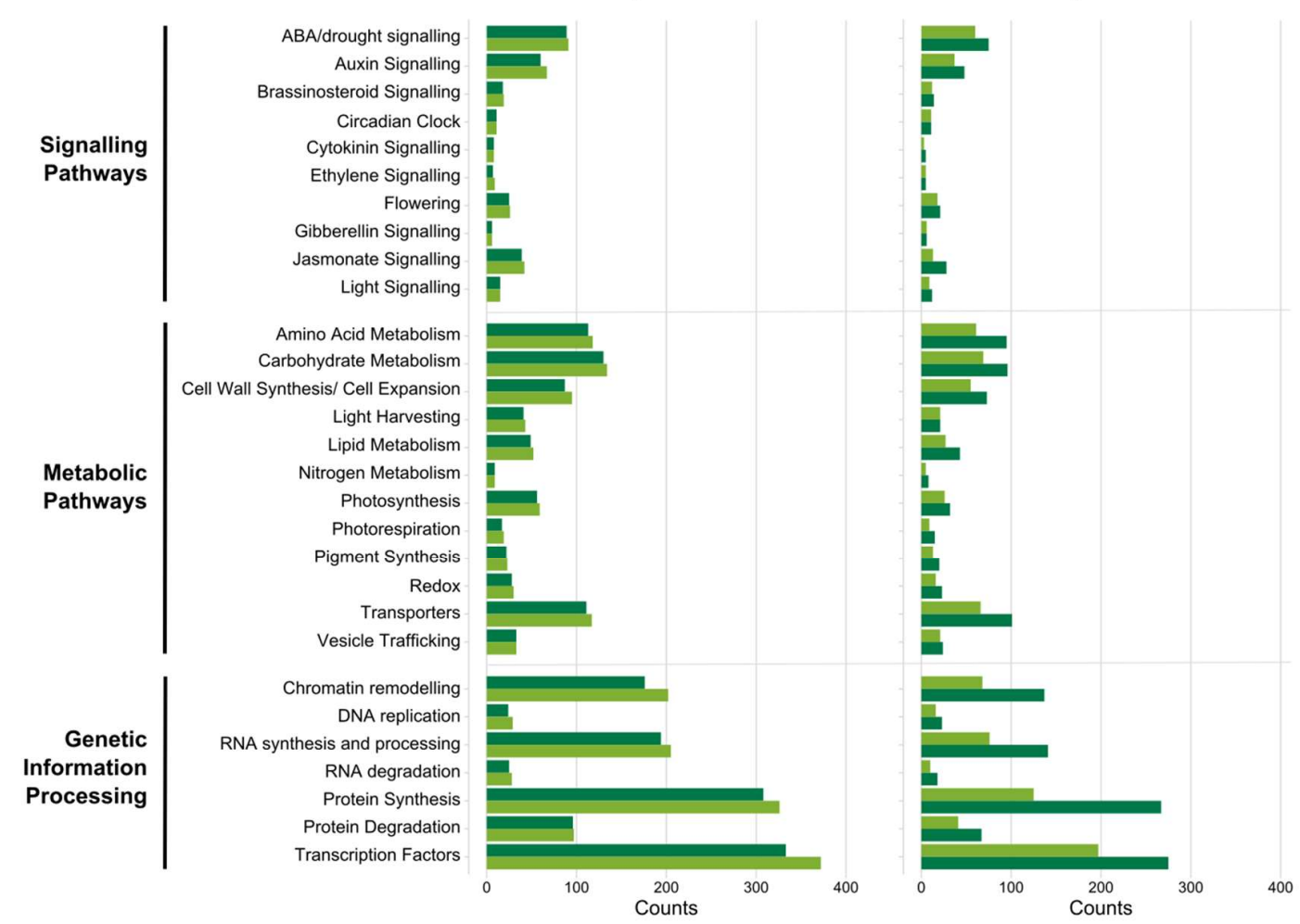

Fig. S3 - Rhythmic co-expression modules that were identified in 4-months-old sugarcane leaves. 9-months-0ld-sugareane has more rhythmic transeripts than-4-months-0ld sugarcane. (a) The number of expressed and rhythmic transcripts detected in the leaves of 4months-old (4 mo) and 9 mo sugarcane in field-grown (diel) conditions and 3 mo leaves in circadian conditions published in Hotta et al. (2013)(Hotta et al., 2013). (b) Distribution of the peak time of rhythmic transcripts in 4 mo and 9 mo sugarcane. (c) Distribution of the functional categories of expressed and rhythmic transcripts in 4 mo (dark green) and 9 mo (light green)

731 sugarcane. 
bioRxiv preprint doi: https://doi.org/10.1101/2021.04.08.439063; this version posted June 25, 2021. The copyright holder for this preprint (which was not certified by peer review) is the author/funder, who has granted bioRxiv a license to display the preprint in perpetuity. It is made available under aCC-BY-ND 4.0 International license.

a 4-months-old - Expressed and rhythmic

C

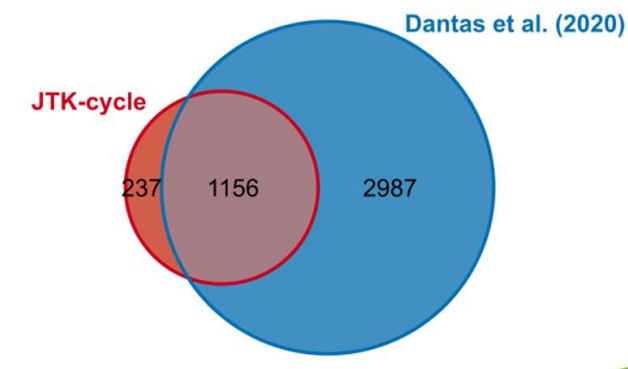

b 9-months-old - Expressed and rhythmic

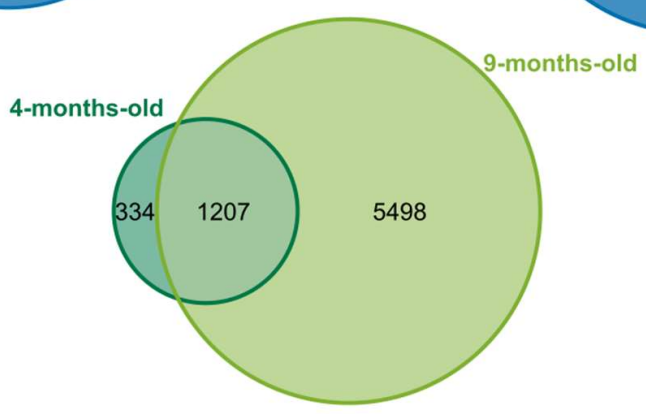

d

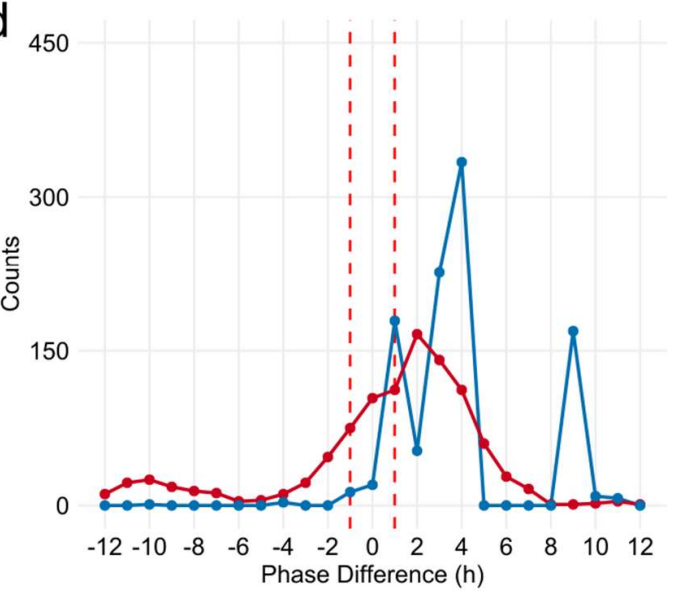

e

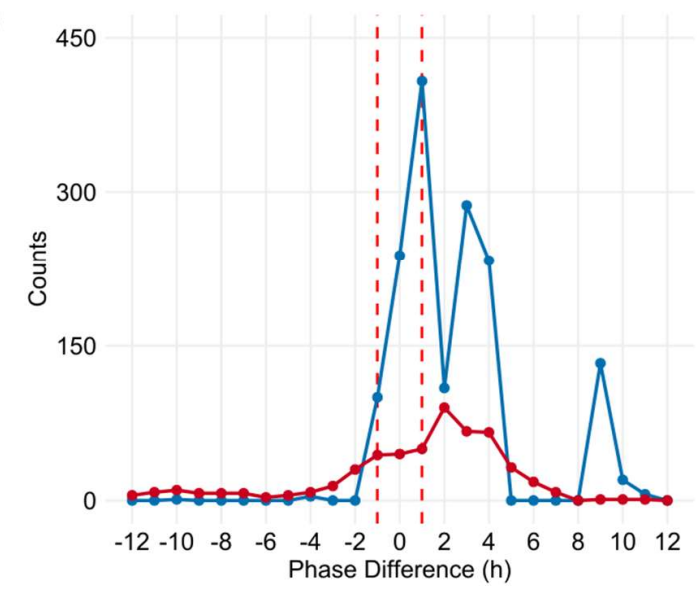

Fig. S4 - Phase changes between rhythmic transcripts in 4-month-old and 9-month-old compared with the WGCNA and JTK-Cycle used in Dantas et al. (2020) transcripts (red) in (a) 4month-old (4 mo) and (b) 9 mo sugarcane leaves using Euler diagrams. (c) Euler diagram of the rhythmic transcripts identified by JTK-Cycle in 4 mo (dark green) and 9 mo sugarcane leaves (green). (c-d) Distribution of phase differences between rhythmic transcripts from 4 mo and 9 mo sugarcane using (d) JTK-Cycle and (e) maSigPro. Phase differences were estimated using JTK-

741 Cycle (red) or LOESS (blue). Differences under $\pm 1 \mathrm{~h}$ are not considered significant (red dashed 742 line). 
bioRxiv preprint doi: https://doi.org/10.1101/2021.04.08.439063; this version posted June 25, 2021. The copyright holder for this preprint (which was not certified by peer review) is the author/funder, who has granted bioRxiv a license to display the preprint in perpetuity. It is made available under aCC-BY-ND 4.0 International license.

\section{Supplemental Figure 5}

a

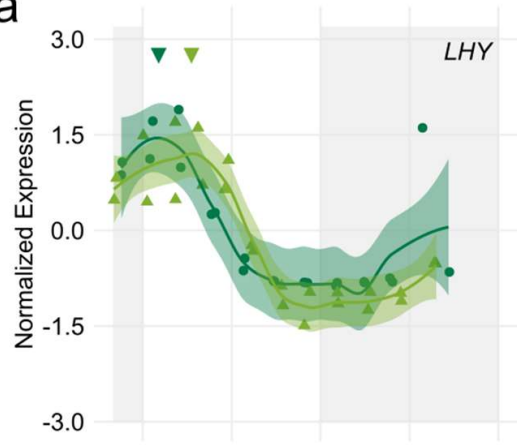

d

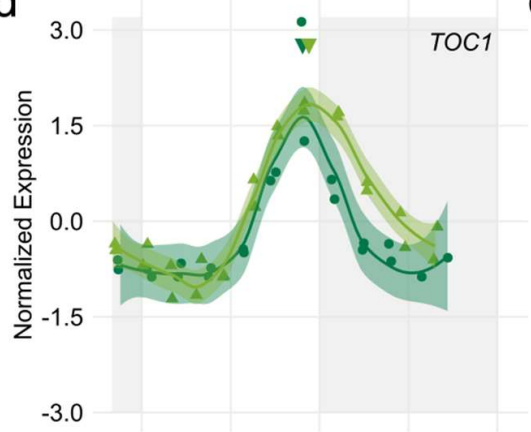

g

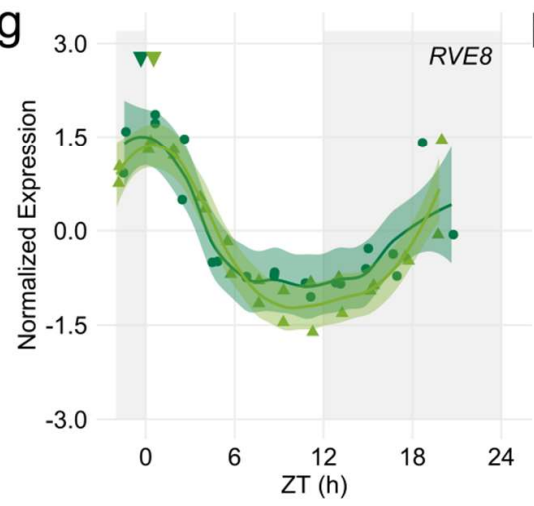

b

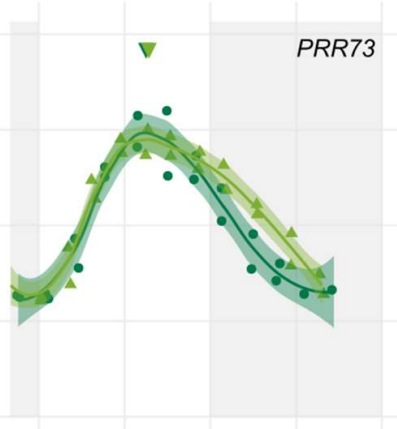
(1)

e

- 4-months-old $\equiv$-months-old

C

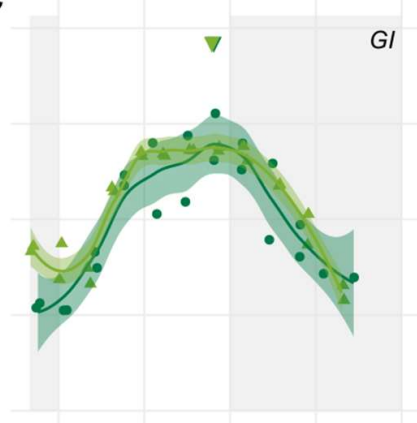

$f$
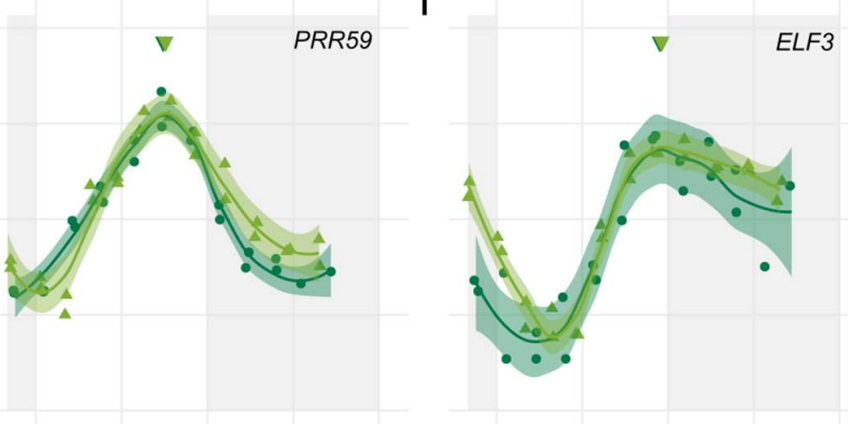

h

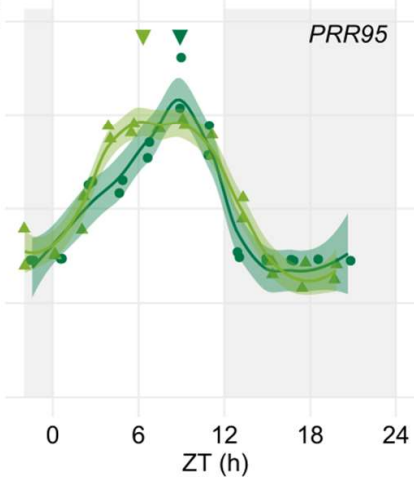

i

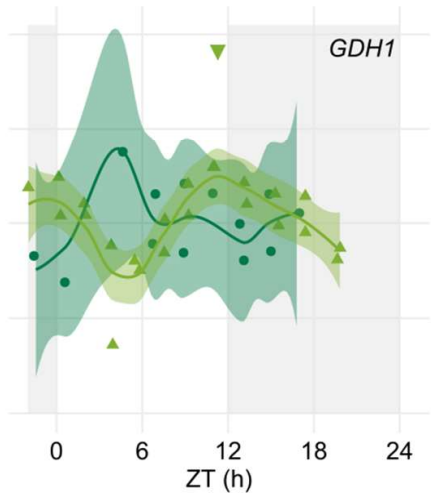

Fig. S5 - Rhythms of circadian clock genes and $N$ metabolism genes in the leaves of 4 arrays in the leaves of 4 mo and 9 mo sugarcane grown in the field. All biological replicates and their LOESS curve (continuous lines \pm SE) are shown. Inverted triangles show the time of the maximum value of the LOESS curve. Time series were normalized using Z-score. To compare the rhythms of samples harvested in different seasons, the time of harvesting (ZT) was

752 normalized to a photoperiod of $12 \mathrm{~h}$ day $/ 12 \mathrm{~h}$ night. The light-grey boxes represent the night 753 periods. 
bioRxiv preprint doi: https:/doi.org/10.1101/2021.04 08.439063: this version posted June 25,2021 . The copyright holder for this preprint (which was not certified by peer review) is the author/funder, who has granted bioRxiv a license to display the preprint in perpetuity. It is made available under aCC-BY-ND 4.0 International license.

\section{Supplemental Fig. 6}
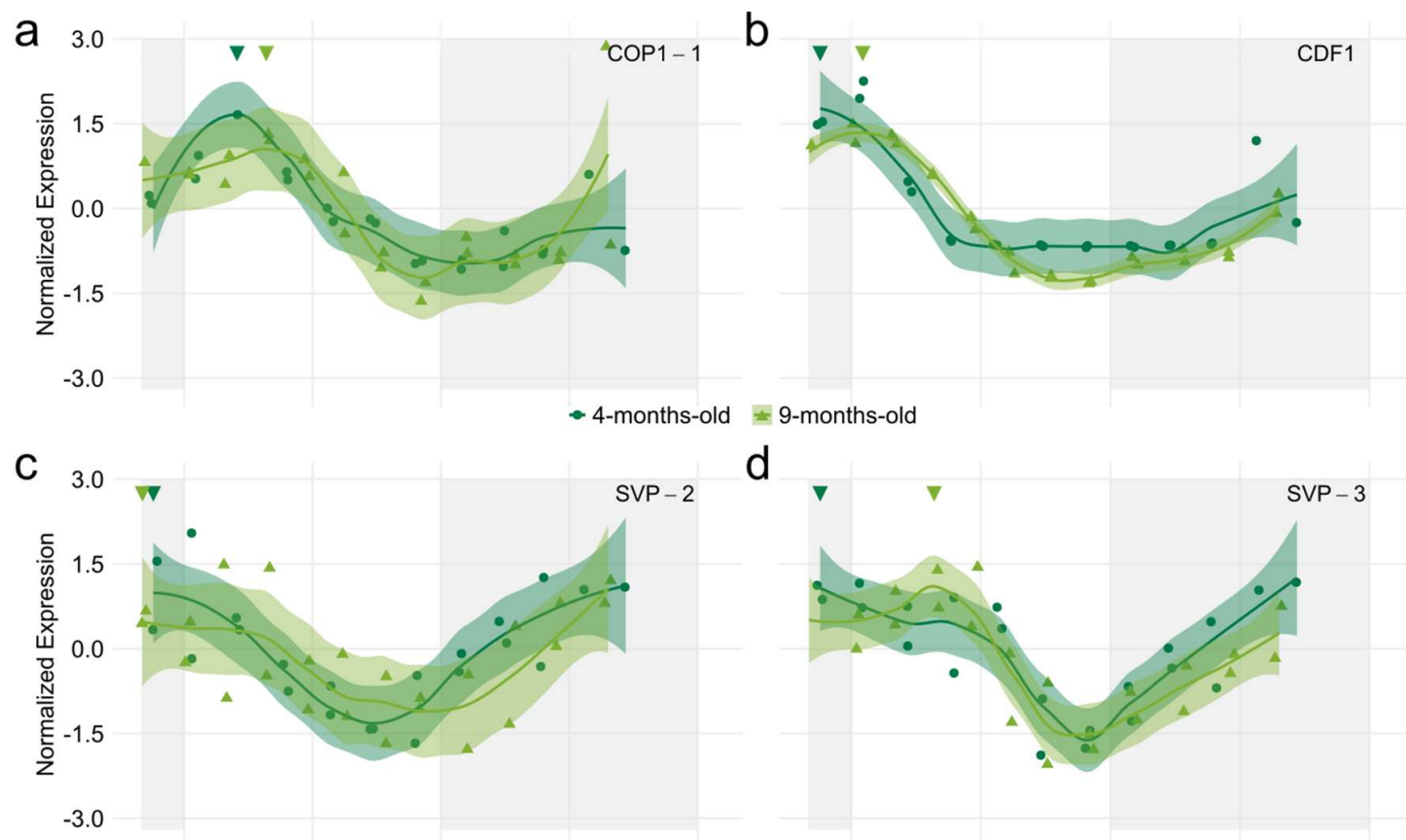

d

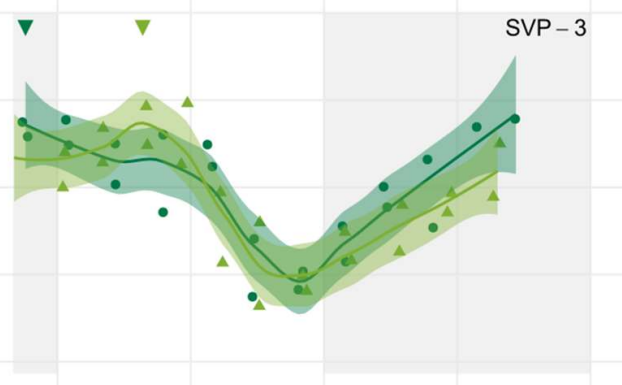

e $\quad 3.0$

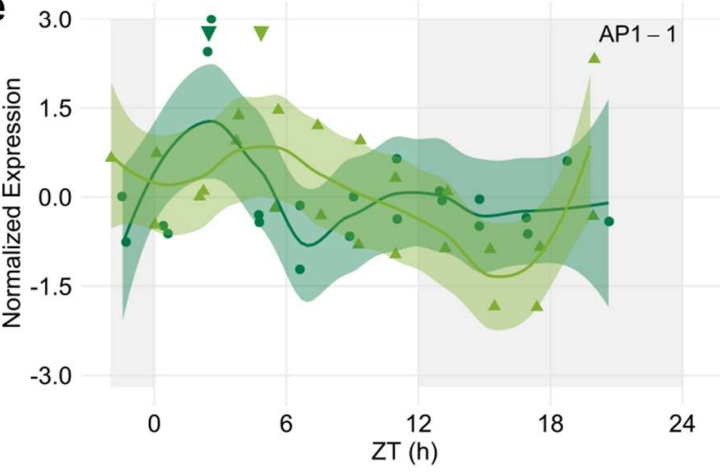

$f$

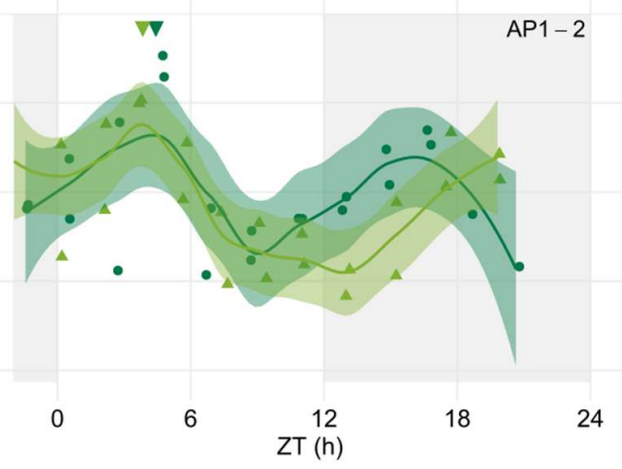

Fig. S6 - Rhythms of genes associated with flowering in the leaves of $\mathbf{4}$ months old and 9 months old sugarcane. Rhythms of (a) CONSTITUTIVE PHOTOMORPHOGENIC 1 (ScCOP1), (b) CYCLING DOF FACTOR1 (ScCDF1), (c) SHORT VEGETATIVE-1 (ScSVP-2), (d) ScSVP-3, (e) APETALA1-1 (ScAP1-1), and (f) ScAP1-2 were measured using custom Agilent oligo arrays in the leaves of 4 mo and 9 mo sugarcane grown in the field. All biological replicates and their LOESS curve (continuous lines $\pm \mathrm{SE}$ ) are shown. Inverted triangles show the time of the maximum value of the LOESS curve. Time series were normalized using Z-score. To compare the rhythms of samples harvested in different seasons, the time of harvesting (ZT) was

764 normalized to a photoperiod of $12 \mathrm{~h}$ day/ $12 \mathrm{~h}$ night. The light-grey boxes represent the night 765 periods. 
bioRxiv preprint doi: https://doi.org/10.1101/2021.04.08.439063; this version posted June 25, 2021. The copyright holder for this preprint (which was not certified by peer review) is the author/funder, who has granted bioRxiv a license to display the preprint in perpetuity. It is made available under aCC-BY-ND 4.0 International license.

\section{Supplemental Figure 7}

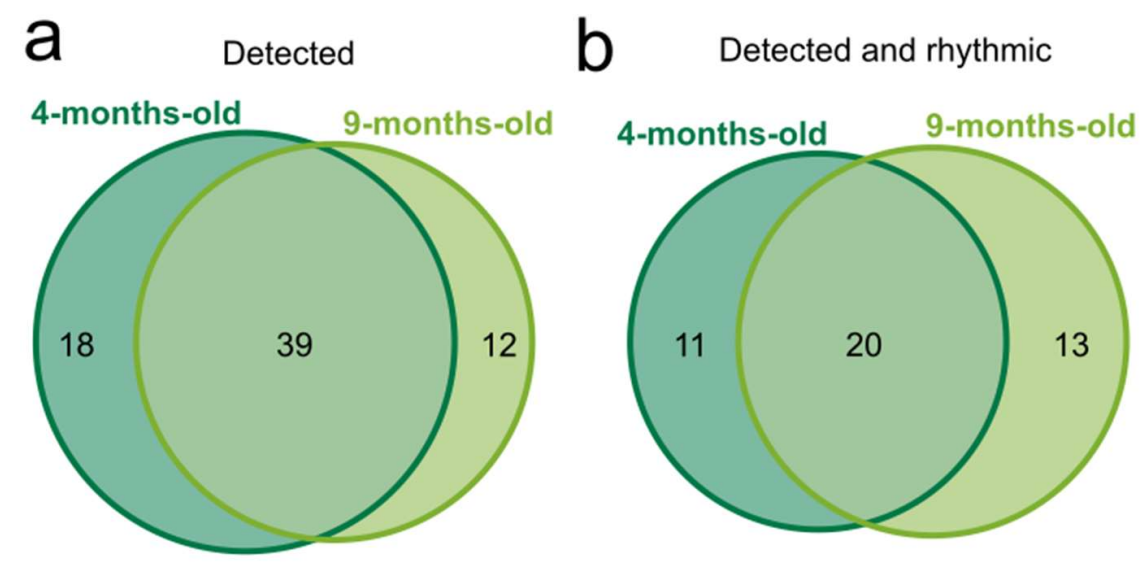

769 Fig. S7 - Euler diagram of detected and rhythmic metabolites. Euler diagrams of all (a) 770 detected metabolites and (b) rhythmic metabolites in 4 mo (dark green) and 9 mo (light green) 771 sugarcane leaves in diel conditions. 
bioRxiv preprint doi: https://doi.org/10.1101/2021.04 08.439063; this version posted June 25, 2021. The copyright holder for this preprint (which was not certified by peer review) is the author/funder, who has granted bioRxiv a license to display the preprint in perpetuity. It is made available under aCC-BY-ND 4.0 International license.

a

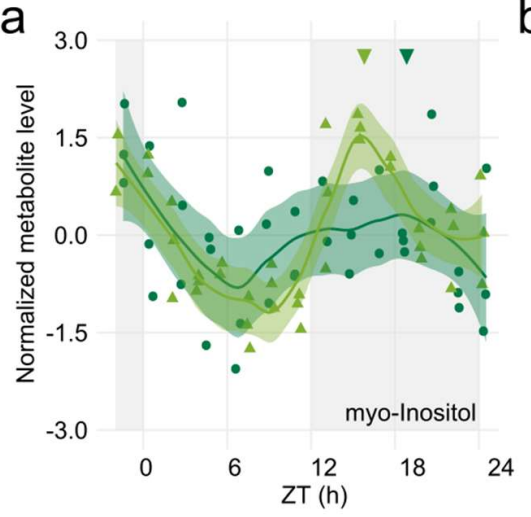

775 light-grey boxes represent the night period. b

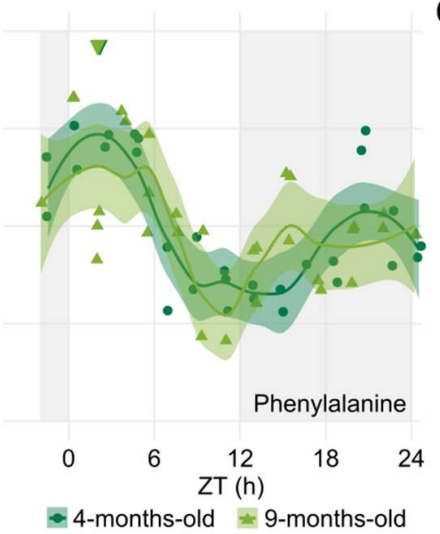

C

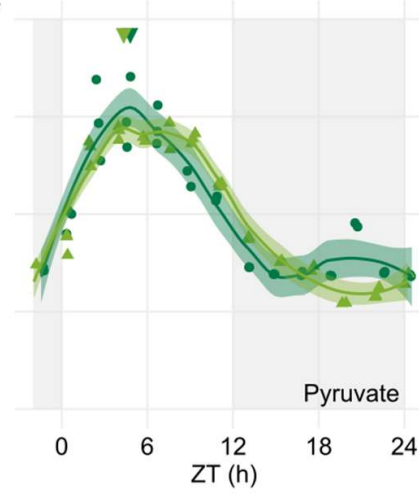

Fig. S8 - Metabolite rhythms that had an early phase or no phase change in 9 months old sugarcane compared to 4 months old sugarcane. Leaf +1 of sugarcane grown for 4 months old (4 mo, dark green) and 9 mo (light green) in the field were harvested for 26 h. Rhythms of (a) myo-Inositol, (b) Phenylalanine and (c) Pyruvate in 4 mo and 9 mo Metabolite levels were normalized with Z-score. All biological replicates (circles in 4 mo and triangles in 9 mo) and their LOESS curve (continuous lines $\pm \mathrm{SE}$ ) are shown. Inverted triangles show the time of the maximum value of the LOESS curve. To compare the rhythms of samples harvested in different seasons, the time of harvesting (ZT) was normalized to a photoperiod of $12 \mathrm{~h}$ day/ $12 \mathrm{~h}$ night. The 
bioRxiv preprint doi: https://doi.org/10.1101/2021.04.08.439063; this version posted June 25, 2021. The copyright holder for this preprint (which was not certified by peer review) is the author/funder, who has granted bioRxiv a license to display the preprint in perpetuity. It is made available under aCC-BY-ND 4.0 International license.
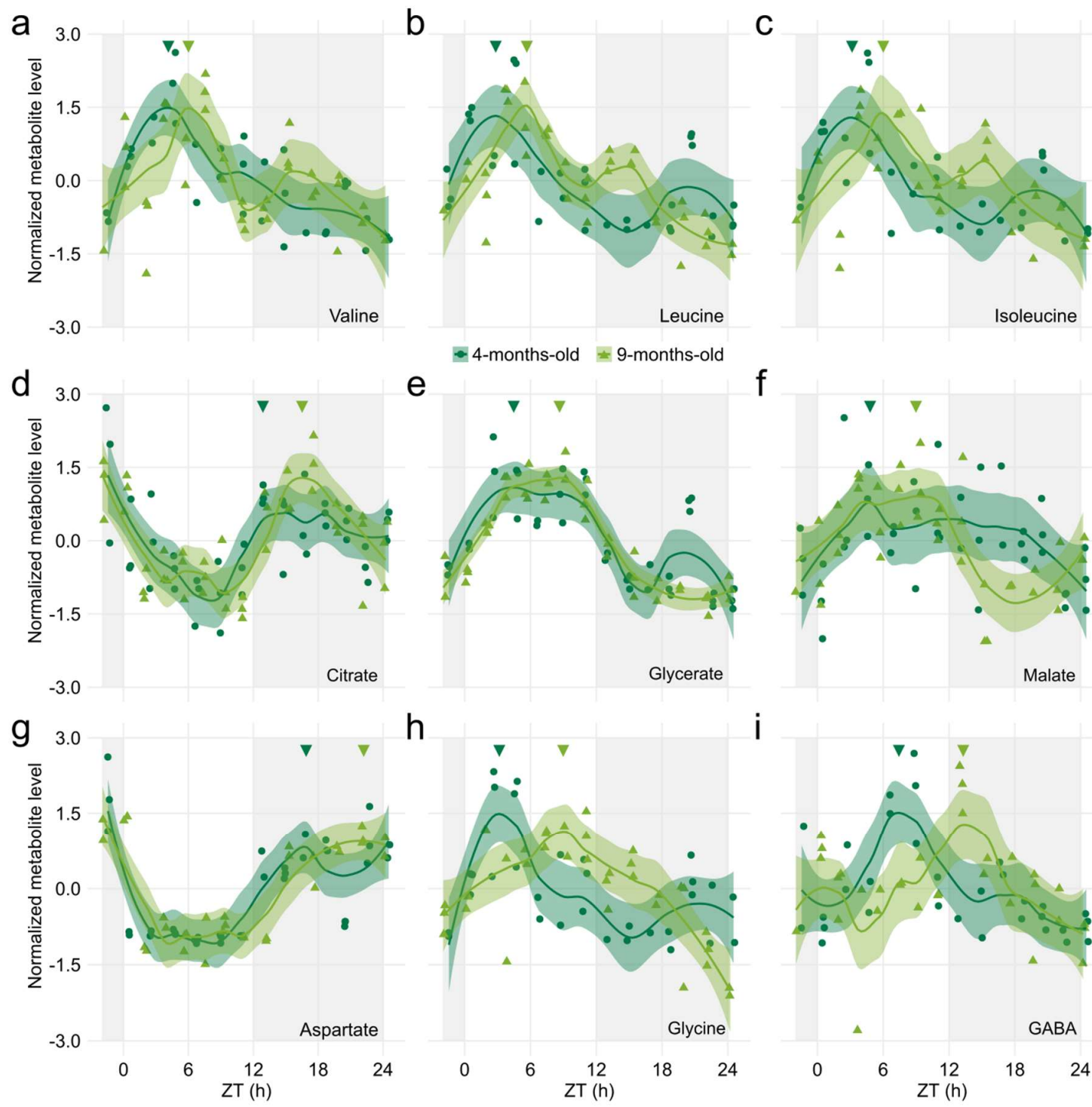

$\mathrm{h}$

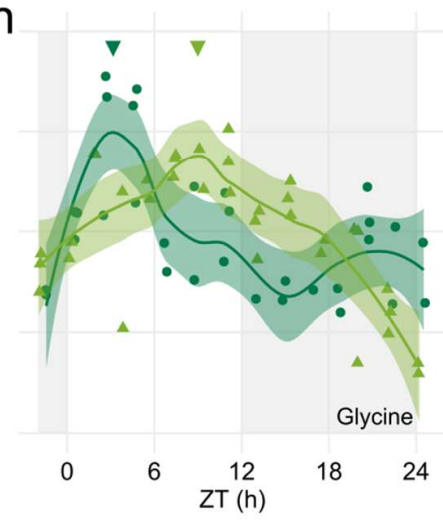

\section{i}

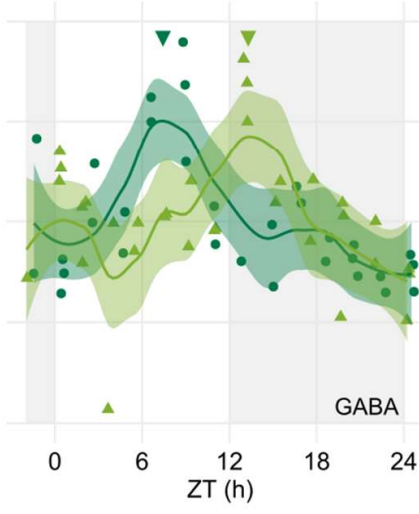

Fig. S9 - Metabolite rhythms that had a phase increase smaller or equivalent to $6 \mathrm{~h}$ in 9 months old sugarcane compared to 4 months old sugarcane. Leaf +1 of sugarcane grown for 4 months old (4 mo, dark green) and 9 mo (light green) in the field were harvested for $26 \mathrm{~h}$. Rhythms of (a) Valine, (b) Leucine, (c) Isoleucine, (d) Citrate, (e) Glycerate, (f) Malate, (g) Aspartate, (h) Glycine, and (i) GABA in 4 mo and 9 mo sugarcane leaves. Metabolite levels were normalized with Z-score. All biological replicates (circles in 4 mo and triangles in 9 mo) and their LOESS curve (continuous lines \pm SE) are shown. Inverted triangles show the time of the maximum value of the LOESS curve. To compare the rhythms of samples harvested in different seasons, the time of harvesting (ZT) was normalized to a photoperiod of $12 \mathrm{~h}$ day/ $12 \mathrm{~h}$ night. The light-grey boxes represent the night period. 
bioRxiv preprint doi: https://doi.org/10.1101/2021.04 08.439063; this version posted June 25, 2021. The copyright holder for this preprint (which was not certified by peer review) is the author/funder, who has granted bioRxiv a license to display the preprint in perpetuity. It is made available under aCC-BY-ND 4.0 International license.

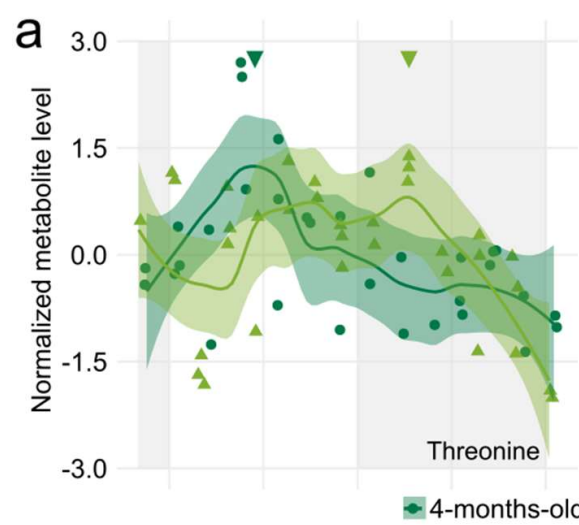

b
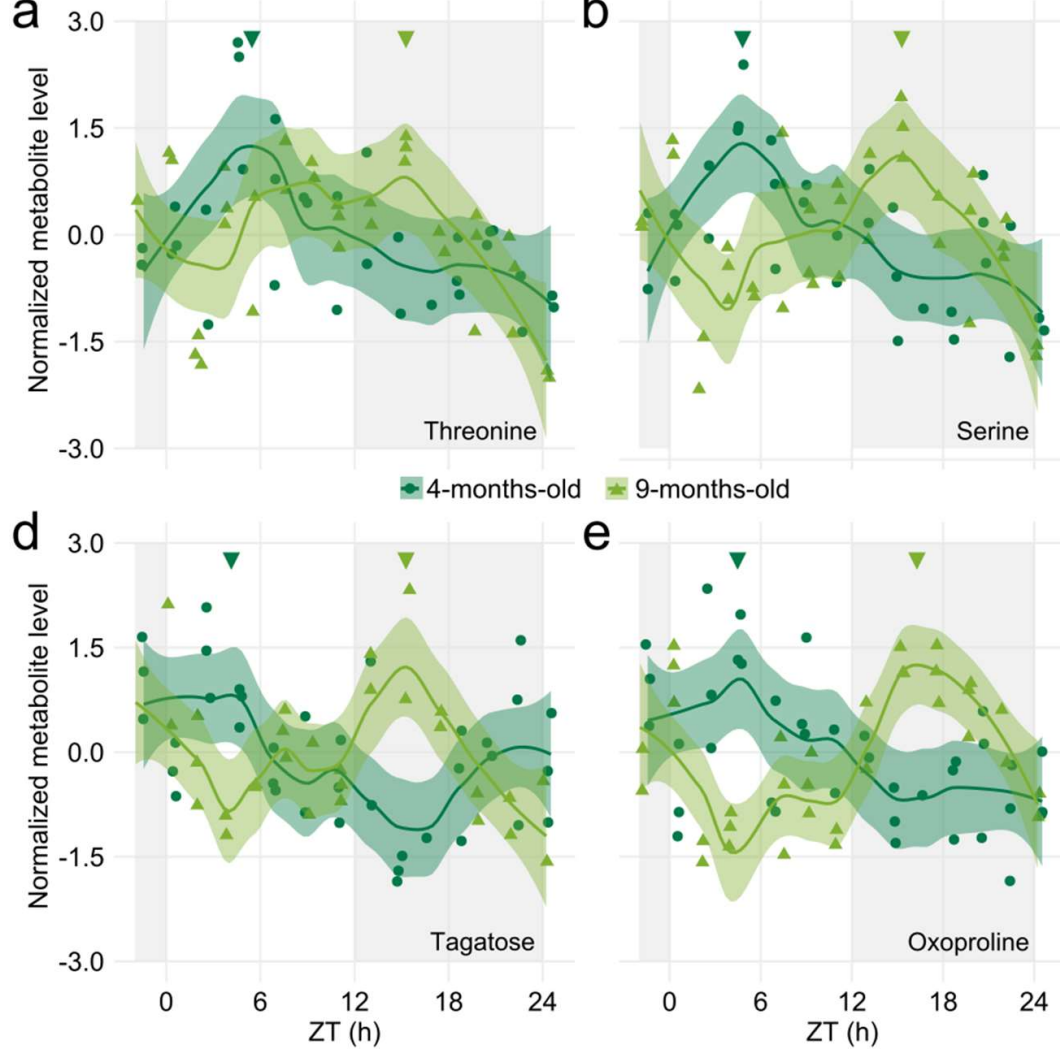

Fig. S10 - Metabolite rhythms that had a phase increase larger than $6 \mathrm{~h}$ in 9 months old sugarcane compared to 4 months old sugarcane. Leaf +1 of sugarcane grown for 4 months old (4 mo, dark green) and 9 mo (light green) in the field were harvested for $26 \mathrm{~h}$. Rhythms of (a) Threonine, (b) Serine, (c) Tagatose and (d) Oxoproline in 4 mo and 9 mo Metabolite levels were normalized with Z-score. All biological replicates (circles in 4 mo and triangles in 9 mo) and their LOESS curve (continuous lines $\pm \mathrm{SE}$ ) are shown. Inverted triangles show the time of the maximum value of the LOESS curve. To compare the rhythms of samples harvested in different seasons, the time of harvesting (ZT) was normalized to a photoperiod of $12 \mathrm{~h}$ day/ $12 \mathrm{~h}$ night. The light-grey boxes represent the night period. 
bioRxiv preprint doi: https:/doi.org/10.1101/2021.04.08.439063: this version posted June 25,2021 . The copyright holder for this preprint (which was not certified by peer review) is the author/funder, who has granted bioRxiv a license to display the preprint in perpetuity. It is made available under aCC-BY-ND 4.0 International license.

\section{Supplemental Figure 11}
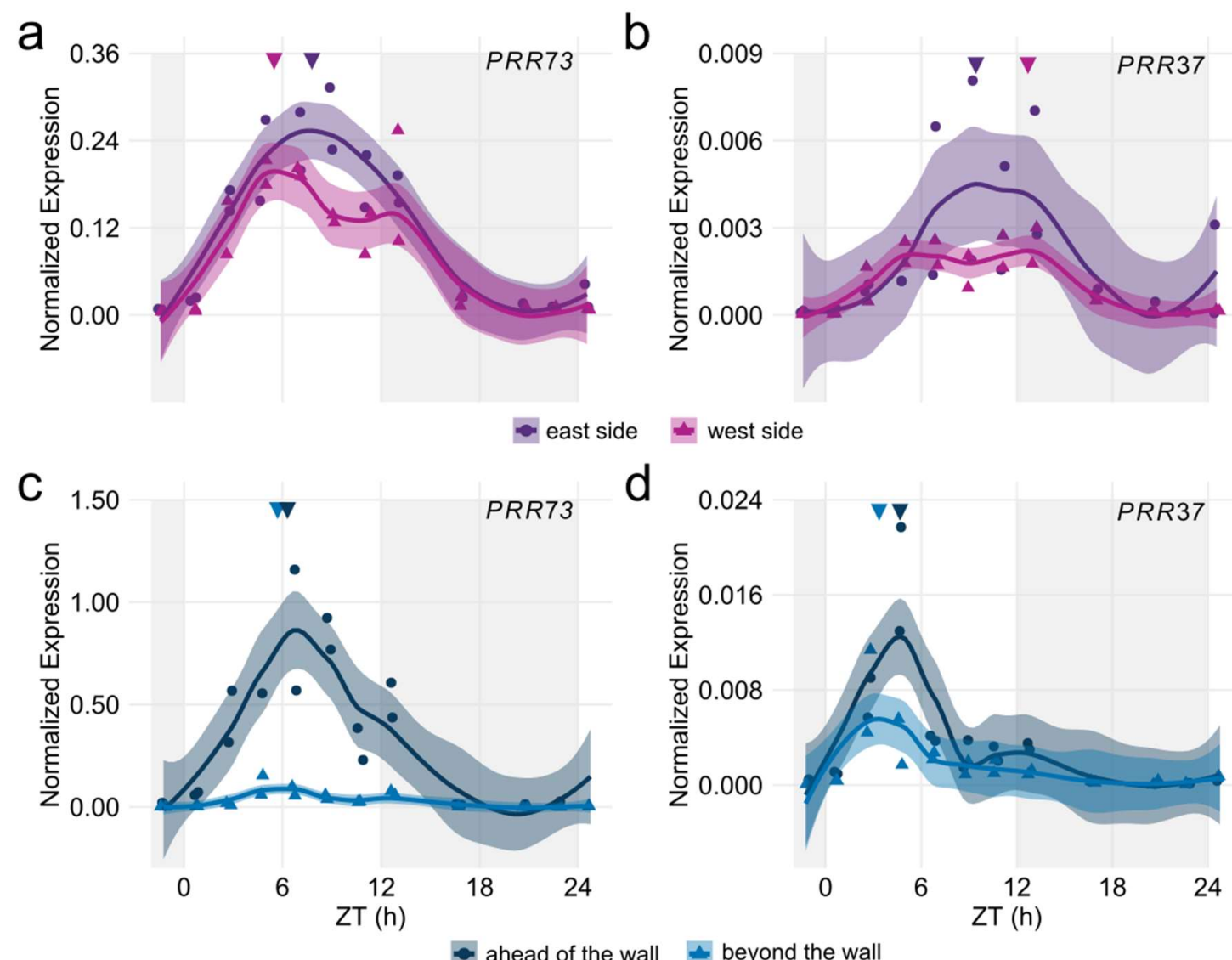

Fig. S11 - Sugarcane leaves have different $S c P R R 73$ and $S c P R R 37$ patterns when shaded at 814 dawn. (a-b) Diel rhythms of (a) PSEUDO-RESPONSE REGULATOR 73 (SCPRR73) and (b) $815 S C P R R 37$ in the leaves of sugarcane grown on the east side (purple) and the west side (pink) of 816 the field. (c-d) Diel rhythms of (c) $S c P R R 73$ and (d) $S c P R R 37$ in the leaves of sugarcane grown 817 ahead of the wall (dark blue) and beyond the wall (light blue). All biological replicates and their 818 LOESS curve (continuous lines $\pm \mathrm{SE}$ ) are shown. Inverted triangles show the time of the 819 maximum value of the LOESS curve. Time series were normalized using Z-score. To compare 820 the rhythms of samples harvested in different seasons, the time of harvesting (ZT) was 821 normalized to a photoperiod of $12 \mathrm{~h}$ day/ $12 \mathrm{~h}$ night. The light-grey boxes represent the night 822 periods. Transcript levels were measured using RT-qPCR. 
bioRxiv preprint doi: https://doi.org/10.1101/2021.04.08.439063: this version posted June 25,2021 . The copyright holder for this preprint (which was not certified by peer review) is the author/funder, who has granted bioRxiv a license to display the preprint in perpetuity. It is made available under aCC-BY-ND 4.0 International license.

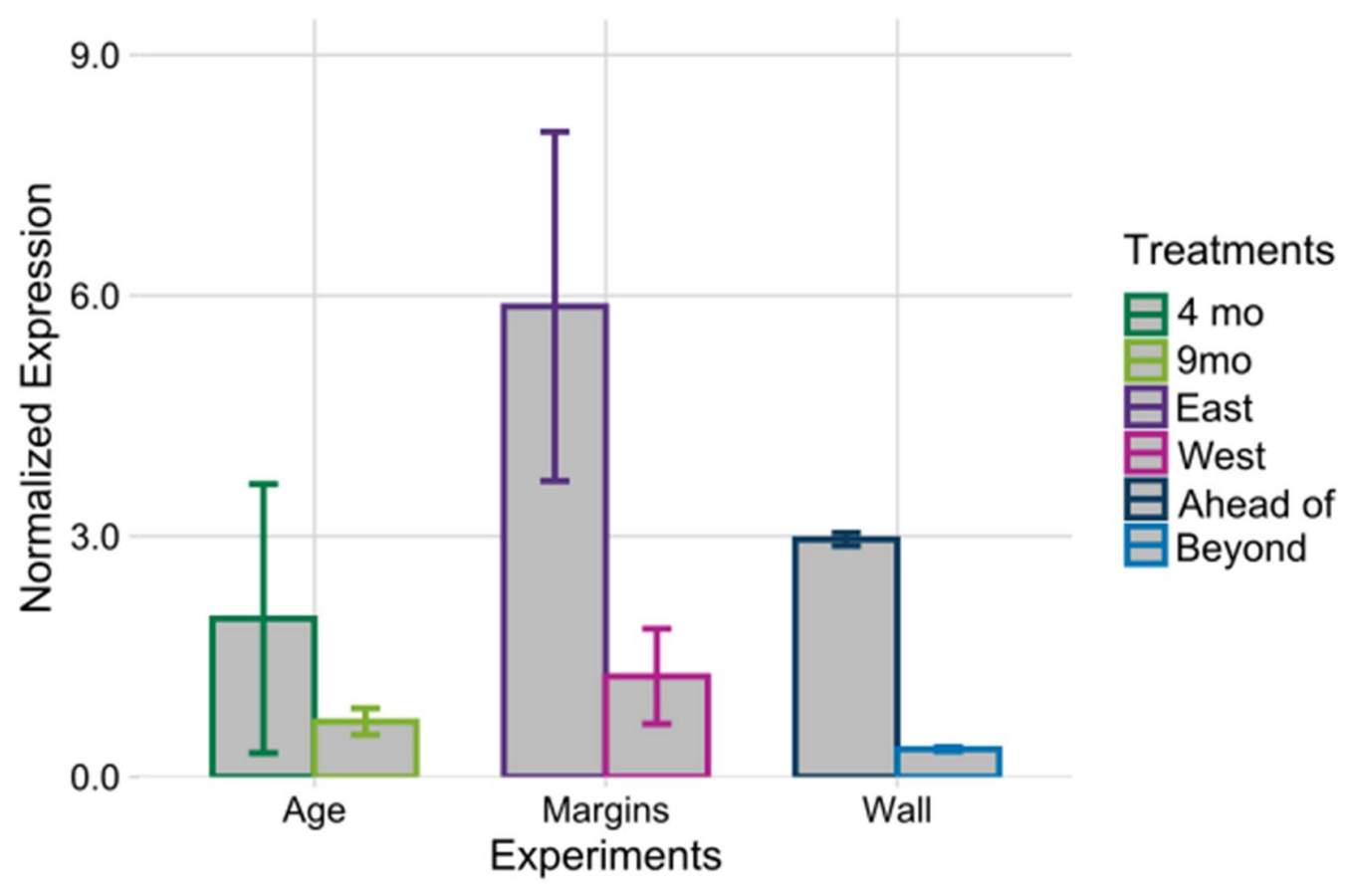

827 Fig. S12 - Transcript levels of ScLHY in the first hours of the morning. In the Age

828 experiment, 4-months-old (dark green) and 9-months-old (light leaves) sugarcane leaves were used. In the Margins experiment, sugarcane leaves from the East side (purple) or the West side (pink) of the sugarcane field were taken. In the Wall experiment, sugarcane leaves were taken from plants ahead of the wall (dark blue) and beyond the wall (light blue) on the east side of the field. Sugarcane leaves were harvested between ZT0 and ZT2 $(n=3)$. Transcript levels were PHOSPHATE DEHYDROGENASE (SCGAPDH). 
836 Table S1 - Sugarcane genes and GenBank IDs.

\begin{tabular}{llll}
\hline Gene & Gene Name & SAS* & GenBank ID \\
Svmbol & & & \\
\hline AP1 & APETALA1 & SCQGLR1085G10.g & CA124279.1 \\
CDF1 & CYCLING DOF FACTOR1 & SCMCCL6053D03.g & CA098046.1 \\
COP1 & CONSTITUTIVE PHOTOMORPHOGENIC 1 & SCCCCL6003C08.g & CA096699.1 \\
ELF3 & EARLY-FLOWERING 3 & SCEZLB1009F09.g & CA113166.1 \\
FLD & FLOWERING LOCUS D & SCEQRT2090F09.g & CA138853.1 \\
FT & FLOWERING LOCUS T & SCBFSD2035E11.g & CA278114.1 \\
GAPDH & GLYCERALDEHYDE-3-PHOSPHATE & SCQGAM2027G09.g & CA086777.1 \\
GI & GIGANTEA & SCJFAD1014B07.b & CA067312.1 \\
LHY & LATE ELONGATED HYPOCOTYL & SCCCLR1048E10.g & CA167119.1 \\
PRR37 & PSEUDO-RESPONSE REGULATOR 37 & Contig 0151209 & - \\
PRR59 & PSEUDO-RESPONSE REGULATOR 59 & SCACLR1057G02.g & CA116370.1 \\
PRR73 & PSEUDO-RESPONSE REGULATOR 73 & SCACLR1057C07.g & CA116387.1 \\
PRR95 & PSEUDO-RESPONSE REGULATOR 95 & SCCCLR1077F09.g & CA120437.1 \\
RVE8 & REVEILLE 8 & SCSGST1070F10.g & CA179134.1 \\
SVP-1 & SHORT VEGETATIVE-1 & SCCCLR1C05A05.g & CA189804.1 \\
SVP-2 & SHORT VEGETATIVE-2 & SCCCLR1072F01.g & CA119595.1 \\
SVP-3 & SHORT VEGETATIVE-3 & SCCCLR2001F11.g & CA127026.1 \\
SOC1 & SUPPRESSOR OF CONSTANS OVEREXPRESSION 1 & SCCCLR2C03H07.g & CA127525.1 \\
TOC1 & TIME OF CAB EXPRESSION 1 & SCCCSB1002H04.g & CA167119.1 \\
\hline 837 & SUgar & &
\end{tabular}

$837 *$ Sugarcane Assembled Sequence. 
839 Table S2 - Sugarcane primers pairs used to validate oligo arrays expression levels using 840 RT-qPCR.

\begin{tabular}{|c|c|c|c|}
\hline Gene Symbol & SAS & Oligonucleotide sequence (5' -> 3') & Reference \\
\hline ScGAPDH & SCQGAM2027G09.g & $\begin{array}{l}\text { FWD CACGGCCACTGGAAGCA } \\
\text { RVS TCCTCAGGGTTCCTGATGCC }\end{array}$ & $\begin{array}{l}\text { Papini-Terzi et al. } \\
(2005)^{\mathrm{a}}\end{array}$ \\
\hline ScLHY & SCCCLR1048E10.g & $\begin{array}{l}\text { FWD CCACCACGGCCTAAAAGAAA } \\
\text { RVS TGGTTTTGTTGACTTGTCATTTGG }\end{array}$ & $\begin{array}{l}\text { Hotta et al. } \\
\text { (2011)b }\end{array}$ \\
\hline ScPRR37 & Contig 0151209 & $\begin{array}{l}\text { FWD CCCTGCTATGTGGTTCCTC } \\
\text { RVS ATTCTGCCCCTTGGTTCC }\end{array}$ & \\
\hline ScPRR73 & SCACLR1057C07.g & $\begin{array}{l}\text { FWD CAAGTAATTCACCCCAAATCAGAGATA } \\
\text { RVS TCCCATAGATTCATCTTTATTCTCCTTAT }\end{array}$ & \\
\hline ScTOC1 & SCCCSB1002H04.g & $\begin{array}{l}\text { FWD TTCTGCCTGAATTTGGCAAGTG } \\
\text { RVS GGCATCGAGCACACCAATGC }\end{array}$ & $\begin{array}{l}\text { Hotta et al. } \\
(2011) b\end{array}$ \\
\hline
\end{tabular}

${ }^{a}$ Pą411i-Terzi et al. (2005) DNA Research 12:27, https://doi.org/10.1093/dnares/12.1.27

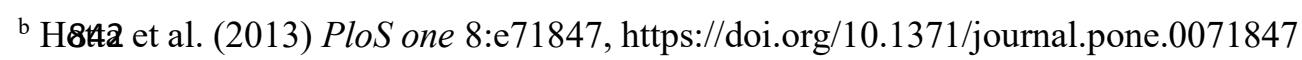

